\title{
İnterdisipliner Eğitim Politikası Üzerine Bir Değerlendirme: Uluslararası İlişkiler ve Kamu Yönetimi Eğitimi
}

\author{
DOI: 10.26466/opus.584916
}

\author{
Merve Mescioğlu Fedai* - Recep Fedai** \\ * Arş. Gör., Ankara Üniversitesi, Uluslararası İlişkiler Bölümü \\ E-Posta: mervemescioglu@gmail.com \\ ORCID: 0000-0001-9177-077X \\ ** Dr. Öğr. Üyesi, Çanakkale Onsekiz Mart Üniversitesi, Finans Bankacıllk Sigortacılık Bölümü \\ E-Posta: recepfedai.86@gmail.com \\ ORCID: $\underline{0000-0002-5547-0048}$
}

\section{$\ddot{O} z$}

Eğitim bir ülkenin hassas politka alanlarından biri olarak oldukça önem taşıyan bir konudur. Üniversiteler ise öğrencilerin meslek sahibi olmadan önceki aldıkları son eğitim kurumu olarak ön plana çıkmaktadır. Bu çalışmada 2018 yıl YÖKATLAS verilerine göre üniversitelerin siyaset bilimi, siyaset bilimi ve uluslararası ilişkiler, uluslararası ilişkiler ve kamu yönetimi bölümlerinin ders programları ele alınmıştır. Çalışma ile üniversitelerin lisans eğitimi veren ilgili alanlarına yönelik ders programlarının analiz edilmesi amaçlanmaktadır. Çalışma Türkiye'de bulunan devlet ve vakıf üniversitelerinin aktif olarak açık ve ders yapılan Kamu Yönetimi ve Uluslararası İlişkiler bölümlerine ait ders planları ve ders içeriklerinin içerik analizine tabi tutulması ile hazırlanmıştır. Ancak çalışmaya SBKY ve Siyaset Bilimi ve Uluslararası İlişkiler bölümleri de dahil edilmiştir. Buna göre Kamu Yönetimi ve SBKY bölümlerinde yer alan uluslararası ilişkiler dersleri; Uluslararası İlişkiler ve Siyaset Bilimi, Uluslararası İlişkiler bölümlerinde eğitimi verilen kamu yönetimine ait dersler ve ders içerikleri analiz edilmiştir. Analizler sonucunda farklllaşmanın nerden kaynaklandığ tespit edilerek bölümlere ilişkin özgün uygulamalara yer verilerek faydalı olduğu düşünülen uygulamaların nasıl yaygınlaştırlabileceği üzerine bir değerlendirme yapılmıştır. Söz konusu bölümlerin lisans eğitiminde birbirlerinden ne derece yaralandı̆̆ı gerek ders içerikleri gerekse bölümlere ait öğretim üyesi vb. diğer bilgileri üzerinden birbirleri ile karşılaştırılmıştır. Çalışma ile kamu yönetimi ve uluslararası iliş̧kiler disiplinlerinin üniversitelerin söz konusu bölümleri açısından ders içerikleri ve planlarına nasıl yerleştirildiği üzerinde durulmakta; ders planlamasının akademik önceliklere dayalı mı yapıldı̆̆ yoksa farklı bir öncelik (popüler bölümler-prestij katma, hocalarm eğitim durumu ve uzmanlık alanı, ihtiyaçlara cevap verme) doğrultusunda mı yapıldığı tespiti yapılmaktadır. Bunlara ilave olarak çalışmanın akademik program hazırlı̆̆ı açısından üniversitelere yol gösterici bir niteliğe kavuşması hedeflenmektedir.

Anahtar Kelimeler: Uluslararası İlişkiler Ĕ̆itimi, Kamu Yönetimi Eğitimi, Yükseköğretim Kurulu, Üniversiteler 


\title{
An Evaluation on Interdisciplinary Education Policy: International Relations and Public Administration Education
}

\begin{abstract}
Education is a very important issue as one of the sensitive policy areas of a country. Universities, on the other hand, come to the forefront as the last educational institution that students take before becoming a profession. In this study, according to the 2018 YÖKATLAS data, the curriculums of the departments of political science, political science and international relations, international relations and public administration of the universities were discussed. The aim of the study is to analyze the curriculums of the universities in the related fields that provide undergraduate education. The study was prepared by an active open and Public Administration course made and subjected to content analysis of lesson plans and course contents of the International Relations department of state and private universities in Turkey. However, PSPA and Political Science and International Relations departments were also included in the study. According to this, international relations courses in Public Administration and PSPA departments; The courses and the contents of public administration courses in International Relations and Political Science and International Relations departments were analyzed. As a result of the analyzes, the origin of the differentiation was determined and an assessment was made on how to spread the applications that are thought to be beneficial by giving specific applications to the departments. The degree to which these departments have been injured from each other in undergraduate education should be explained both by the course contents and by the faculty members of the departments. Other information is compared with each other. The study focuses on how the disciplines of public administration and international relations are placed in the course contents and plans for the said departments of the universities; whether the course planning is based on academic priorities or a different priority (popular sections - adding prestige, teaching status and expertise of the instructors, responding to needs). In addition to this, it is aimed that the study will become a guide for universities in terms of preparation of academic program.
\end{abstract}

Keywords: International Relations Education, Public Administration Education, Council of Higher Education, Universities 


\section{Giriş}

Bu çalışma Türkiye'de devlet ve vakıf üniversiteleri bünyesinde kurulan Kamu Yönetimi/SBKY/Uluslararası İlişkiler/Siyaset Bilimi ve Uluslararası İlişkiler bölümlerini gerek ders içerikleri gerekse ders programları üzerinden bir analiz yapma fırsatı sunmaktadır. Yapılacak analiz ile uluslararası ilişkiler eğitiminde kamu yönetimi derslerinin ne oranda yer aldığı belirlenerek uluslararası ilişkiler disiplinin kamu yönetimi disiplininden ne derece yararlandığı değerlendirilecektir. Uluslararası ilişkiler disiplininin sadece dış politikaya odaklı bir eğitim verip vermediğinin araştırılması bu çalışmadan beklenilen sonuçlardan bir tanesidir. Söz konusu disiplinin Türkiye'deki üniversitelerdeki eğitim müfredatının iç politika açısından kullanılması siyaset bilimi ve kamu yönetimi disiplininden yararlanılmasını gerektirmektedir. Kamu politikası analizi derslerinde de çokça karşılaşılan durum, bir ülkenin dış politikasının policy alanlarını belirlemede karar verme sürecine etki etmektedir. Örneğin uluslararası örgütlerin politika yapım sürecindeki rolleri göz önüne alındığında kamu yönetimi disiplini bu gelişmeleri takip etmekte ve bunlar programın ders içeriğine yansıtmakta mıdır? Aynı durum acaba uluslararası ilişkiler disiplini için de geçerli midir? Çalışmada bu sorulara cevap aranacaktır.

Üniversitelerin fakülte bazlı olarak Siyaset Bilimi ve Kamu Yönetimi (SBKY) bölümleri (İkinci öğretim, \%30 İngilizce gibi durumlar hariç) 65 devlet, 17'si vakıf üniversitesi üzere KKTC'de bulunan 2 üniversite ile birlikte 84 üniversitede aktif durumdadır. SBKY bölümlerinin 39'unda ikinci öğretim eğitimi verilmektedir. Kamu Yönetimi bölümü ise 24 devlet üniversitesi 2 vakıf 2 de KKTC olmak üzere toplam 28 üniversite bünyesinde bulunmaktadır. Uluslararası İlişkiler bölümü için durum ise şu şekilde özetlenebilir: Üniversitelerin 59'unda gündüz eğitimi $26^{\prime}$ sında ise gece eğitimi verilmektedir. Söz konusu bölümlerin 20'si vakıf üniversitesinde KKTC'de ise 7 üniversitede bulunmaktadır. Siyaset Bilimi ve Uluslararası İlişkiler bölümü 27 vakıf üniversitesi olmak üzere toplam 43 üniversitede aktiftir. Siyaset bilimi bölümü ise biri devlet üniversitesi ikisi vakıf ikisi de KKTC'de olmak üzere 5 üniversitede aktif olduğu görülmektedir. 
Tablo 1: YÖKATLAS'a Göre Bölümlerin Üniversite Bazında Dağlımı (Öğrencisi Olan Bölümler) ${ }^{1}$

\begin{tabular}{|c|c|c|c|c|}
\hline \multirow[t]{2}{*}{ BÖLÜMLER } & \multicolumn{2}{|c|}{ Devlet } & \multirow[t]{2}{*}{ Vakıf } & \multirow[t]{2}{*}{ Toplam } \\
\hline & N.Ö. & İ.Ö & & \\
\hline Uluslararası İlişkiler & 59 & 26 & 27 & 86 \\
\hline Kamu Yönetimi & 24 & 24 & 4 & 28 \\
\hline Siyaset Bilimi ve & 16 & 6 & 27 & 43 \\
\hline Uluslararası İlişkiler & 65 & 39 & 19 & 84 \\
\hline SBKY & 1 & - & 4 & 5 \\
\hline
\end{tabular}

YÖKATLAS verileri 2017 yılına ait YKS tercihleri ve doluluk oranlarından elde edilen bilgiler olduğu için söz konusu verilerde birtakım eksiklikler bulunmaktadır. 2018-2019 eğitim ve öğretim yılında hangi bölümlere öğrenci alındığı ve aktif olarak eğitime başladıklarının tespiti söz konusu olamamaktadır. Örneğin Siyaset Bilimi bölümü bulunan devlet üniversiteleri YÖKATLAS'ta sadece bir üniversitede (Galatasaray Üniversitesi) görünmektedir. Ancak ilgili üniversitelerin web sayfaları ve ders içerikleri daha detaylı araştırıldığında diğer üniversitelerde de (vakıf dahil) (A. Gül Üniv., Işık Üniv., İstanbul Bilgi Üniv., Sabancı Üniv. gibi) bu bölümün açık olduğu görülmektedir. Çünkü 2018-2019 dönemi fakültelerin geçmiş yıllara oranla daha az öğrencinin kayıt yaptırdığı bir dönem olmuştur. Böylelikle YÖKATLAS'ta öğrenci talep eden bölümlerin bir kısmının ikinci öğretim bölümlerinin boş kaldığı ve aktif olmadığ 1 rahatlıkla söylenebilir.

\section{Literatür Taraması}

Literatürde kamu yönetimi ve uluslararası ilişkiler eğitimine ilişkin çeşitli çalışmalar (kongre, sempozyum ve makale çalışmaları) mevcuttur. Kamu yönetimi eğitimine yönelik ${ }^{2}$ olarak başta Kamu Yönetimi Forum-

\footnotetext{
${ }^{1}$ Toplam sayıya Ikinci Öğretim bölümleri dâhil edilmemiştir.

2 Literatürde kamu yönetimi eğitimine ilişkin çalışmalara değinilecek olursa bu alandaki çalışmaların sayısının azlığı dikkat çekmektedir. Kamu yönetimi çerçevesinde düzenlenen bilimsel kongre ve sempozyumlarda sunulan bildirilerin daha sonra makale çalışmaları ile ayrıntılı bir hal aldığı ifade edilebilir. Örneğin KAYFOR II, 2004 yılında Hacettepe Üniversitesinde Kamu Yönetiminde eğitim ve öğretim teması ile Dönüşüm ve Eğitime Yansımlar başlığı ile düzenlenmiştir. 2019 yılında yine eğitim teması ile Nuh Naci Yazgan Üniversitesinde KAYFOR 16 düzenlenmiştir (KAYFOR, 2019).
} 
ları (KAYFOR) ve Kamu Yönetimi Sempozyumları (KAYSEM) olmak üzere konuya ilişkin çalışmalar sunulmuş ve günümüzde halen bu konuda bilimsel toplantılar sürdürülmektedir. ${ }^{3}$ Uluslararası İlişkiler disiplini için ise iki yılda bir Uluslararası İlişkiler Konseyi (UİK) tarafından düzenlenen kongrelerin yanı sıra farklı isimlerde bilimsel toplantıların olduğu söylenebilir. ${ }^{4}$ İlk defa 1961 yılında Ankara Üniversitesi Siyasal Bilgiler Fakültesi'nde düzenlenen ve uluslararası ilişkiler ${ }^{5}$ eğitimine yönelik olan Milletlerararası Politika Öğretimi Sempozyumu (Dedeoğlu, 2005, s.151-155) kincisi 2005 yılında olmak üzere (ikişer yıl arayla) sekizincisi ise 2018 yılında düzenlenmiştir. Çalışma bağlamında bölümlere ilişkin olarak yapılan makale ve tez çalışmalarına değinilecek olursa: Keyman ve Ülkü (2007, s.99-105) uluslararası ilişkiler eğitimine yönelik olarak kırk iki üniversitenin web sayfasından elde edilen bilgiler doğrultusunda uluslararası ilişkiler bölümlerinin müfredatlarını içerik analizine tabi tutmuştur. Yazarlar çalışmalarında Türkiye'de üniversitelerin ilgili bölümlerinde verilen derslerin yeterli olup olmayacağına dair bir analiz sunmuşlardır. Tepeciklioğlu ise 2012 yılı Temmuz ayı itibariyle Türkiye'de yüz dokuz üniversitede Uluslararası İlişkiler bölümünün olduğunu belirterek bu bölümlerde lisans ve lisansüstü eğitimlere ilişkin okutulan derslerin isimleri, öğrenci ve öğretim üyesi sayısını karşılaştırmiştır (Tepeciklioğlu, 2013). Özcan (2007) Türkiye'de disipline ilişkin lisansüstü eğitimin sorunlarına yer verirken Yalçınkaya ve Efegil (2009) ise çalışmalarında uluslararası ilişkiler disiplini eğitiminde kullanılan metotları ve derslerde okutulan kitapları ele almışlardır. Yüksek Öğretim Kurumu Ulusal Tez Merkezi'nde uluslararası ilişkiler eğitimine ilişkin olarak herhangi bir teze rastlanılmamıştır. Diğer yandan Yüksek Öğretim Kurumu Ulusal Tez Merkezi'nde kamu yönetimi eğitimine ilişkin olarak yüksek lisans ve doktora tez çalışmalarına ulaşılmıştır. Biri doktora dördü ise yüksek lisans düzeyinde olmak üzere beş çalışma bulunmaktadır. Bu çalışmalar arasında doğrudan üniversitelerin verdiği kamu

\footnotetext{
${ }^{3}$ KAYFOR'un 2003 yılından bugüne gelişimi ve kurumsallaşma sürecine yönelik bir değerlendirme için Bkz: (Seçkiner ve Yıldız, 2013, s.110-137).

${ }^{4}$ Uluslararası iliş̧kiler Konseyi Derneği 2004 yılında tüzel kişiliğini kazanmış olup 2005 yılından itibaren faaliyetlerine devam etmektedir. 2008 yılında kurulan Türkiye Uluslararası Ilişskiler Çalışmaları Derneği (TUiÇ) uluslararası ilişkiler eğitimine yönelik çalışmalar düzenlemektedir (UiK, 2019).

${ }_{5}^{5}$ Uluslararası iliş̧kiler disiplinin tarihsel gelişimi için Bkz: (Sezer, 2005, s.30-53).
} 
yönetimi eğitimini inceleyen doktora düzeyindeki çalışmanın en son Alkuş (2000) tarafından yapıldığı görülmektedir.

Yüksek lisans düzeyinde ise doğrudan kamu yönetimi eğimine ilişkin olarak ise Adalı (2010) tarafından yayınlanmıştır. Diğer çalışmalar ise kamu yönetimi eğitimi ile dolaylı olarak yani başka bir konu üzerinden bağdaşmaktadır. Örneğin Polat (2009), çalışmasında kamu yönetimi eğitiminin denetime ilişkin yönlerine ele almış, Yaman (2009) kamu yönetimi eğitimi açısından kamudaki yöneticiler üzerine bir çalışma yapmıştır. ${ }^{6}$ Akpınar (2017) ise kamu yönetimi eğitimi ve istihdamı üzerine bir çalışma yapmıştır. Alana ilişkin olarak yapılan diğer çalışmalar incelendiğinde 2009 yılında yapılan bir çalışmada lisans düzeyinde kamu yönetimi eğitimi alan öğrenciler üzerine bir araştırmanın ${ }^{7}$ sonuçlarının değerlendirildiği görülmektedir. Altan ve arkadaşları (2009) çalışmalarını yedi üniversitede yaptıkları anket çalışması ile kamu yönetimi öğrencilerinin mevcut durumlarından yolan çıkarak kamu yönetimi eğitimini algılamaları (eğitime yönelik bilgi, beklenti) üzerine kurgulamışlardır. Ömürgönülşen'in (2010) makalesinde Türkiye'de lisans düzeyinde kamu yönetimi öğretiminin kurumsal gelişimine yer vererek kamu yönetimi eğitimini geniş ve dar anlamlı olarak açıklamıştır. Yazar kamu yönetimi eğitimini geniş perspektiften siyaset bilimi derslerinin yanı sıra maliye gibi derslere de yer verecek şekilde ele almış; dar anlamlı olarak ise "yönetimi bilimleri anabilim dalının doğrudan sorumluluğundaki" dersleri kastederek kamu yönetimi, yönetim bilimi, personel yönetimi, örgütsel davranış, halkla ilişkiler derslerine ilave olarak idare hukuku, yönetim tarihi, yönetim yapısı, yerel yönetimler, kamu mali yönetimi derslerinin de kamu yönetimi bünyesinde ele alınması gerektiğini belirtmiştir. 2017

\footnotetext{
${ }^{6}$ Yazarın Radyo Iletişim Fakültesi Radyo ve Televizyon Anabilim dalında çalışmasını yaptığı ifade edilmelidir.

${ }^{7}$ Çalışmada kamu yönetimi eğitiminin Tanzimat dönemine kadar götürülebileceği Enderun Mektebinin ise kurumsallaşma adına önemli bir eğitim kurumu olduğu ifade edilmiştir. Buna göre; önemli bir kurum olarak Mekteb-i Mülkiye 1949 yılına gelinceye kadar çeşitli isimler adı altında eğitim faaliyetlerini sürdürmüş ve nihayetinde Ankara Üniversitesi bünyesinde fakülte olarak yer almıştır. Bu dönemi takiben Türkiye Ortadoğu Amme idaresi (TODAIE) kamu yönetimi eğitimi veren başka bir kurum olarak faaliyetlerini sürdürmeye başlamıştır. Daha sonra ODTÜ ve diğer üniversitelerde kamu yönetimi bölümleri açılmıştır. Not: 2018 yılında 703 sayılı Kanun Hükmünde Kararname (KHK) ile TODAIE kapatılmıştır. Anayasada Yapılan Değişikliklere Uyum Sağlanması Amacıyla Bazı Kanun ve Kanun Hükmünde Kararnamelerde Değişiklik Yapılması Hakkında Kanun Hükmünde Kararname, (RG: 09.07.2018, Sayı: 30743). Kamu yönetimi disiplinin gelişimi hakkında ayrıntılı bilgi için Bkz: (Keskin, 2006, s.1-28).
} 
yılında ise Siyaset Bilimi ve Kamu Yönetimi (SBKY) ve Kamu Yönetimi bölümlerine yönelik geniş kapsamlı bir çalışma yapılmıştır. Kiriş ve Gül çalışmalarında (2017, s.2109-2131) Türkiye'de üniversitelerin SBKY ve Kamu Yönetimi bölümlerini belirli kriterlere göre karşılaştırmış ve bir sıraya dizmiştir. Öğrencilerin bölümlere yerleşme puanı, bölümlere ait kontenjanlar, bölümde ders veren hocaların sayısı gibi kriterler üzerinden bölümlere ilişkin bir çerçeve sunulmuştur.

\section{Çalışmanın Yöntemi}

Çalışma Türkiye'de bulunan devlet ve vakıf üniversitelerinin aktif olarak açık ve ders yapılan Kamu Yönetimi ve Uluslararası İlişkiler bölümlerine ait ders planları ve ders içeriklerinin içerik analizine tabi tutulması ile hazırlanmıştır. Ancak çalışmaya SBKY ve Siyaset Bilimi ve Uluslararası İlişkiler bölümleri de dahil edilmiştir. Buna göre Kamu Yönetimi ve SBKY bölümlerinde yer alan uluslararası ilişkiler dersleri; Uluslararası İlişkiler ve Siyaset Bilimi, Uluslararası İlişkiler bölümlerinde eğitimi verilen kamu yönetimine ait dersler ve ders içerikleri analiz edilmiştir. Analizler sonucunda farklılaşmanın nerden kaynaklandığı tespit edilerek bölümlere ilişkin özgün uygulamalara yer verilerek faydalı olduğu düşünülen uygulamaların nasıl yaygınlaştırılabileceği üzerine bir değerlendirme yapılacaktır. Çalışma ile kamu yönetimi ve uluslararası ilişkiler disiplinlerinin üniversitelerin söz konusu bölümleri açısından ders içerikleri ve planlarına nasıl yerleştirildiği üzerinde durulmakta; ders planlamasının akademik önceliklere dayalı mı yapıldığı yoksa farklı bir öncelik (popüler bölümler-prestij katma, hocaların eğitim durumu ve uzmanlık alanı, ihtiyaçlara cevap verme) doğrultusunda mı yapıldığı tespiti yapılacaktır. Bunlara ilave olarak çalışmanın akademik program hazırlığı açısından üniversitelere yol gösterici bir niteliğe kavuşması hedeflenmektedir.

Türkiye'de 2019 yılı Mayıs ayı itibariyle 129 devlet üniversitesi 72 vakıf üniversitesi olmak üzere toplam 201 üniversite bulunmaktadır. Bölümlerin dağılımı yukarıdaki tablodaki gibi iken aktif olmayan bölümler hazırlanan tabloda yer almamıştır. İlgili fakültelerin web sitesinde kimi zaman bölümlerin ismi yer almakta ancak bölümlerin aktif olmadığ1 anlaşılmaktadır. YÖKATLAS hizmetinden yararlanarak çalışmaya konu 
olan bölümlere ilişkin birtakım bilgilere ulaşılsa da YÖKATLAS'ta yer alan bilgilerin 2017 yılına ait olan veriler olduğu fark edilmektedir. Dolayısıyla açık olan ancak bölümde öğrencisi olmayan üniversiteler için böyle bir çalışma yanıltıcı olabilecektir. Doğrusu her üniversitenin kendi web sitesi üzerinden giderek ders içerikleri ve planlarına (EK-1 de olduğu gibi) ulaşmaktır. Bu yöntem ise çalışmayı belirli açılardan çeşitli zorluklara sokmuştur. İlk olarak her üniversitenin web sitesi ile ilgili belli başlı problemler vardır. Çalışmanın tam olarak konusu olmamasına rağmen üniversitelerin web sitelerindeki mevcut eksiklikler bu çalışmanın belki de en büyük zorluğudur. Bunun telafisi için veri elde edilemeyen üniversitelerin ilgili birimlerine ulaşılmaya çalışılmış ve gerekli veriler istenmiştir. Ancak halihazırda dönüş yapmayan birimler olduğu için ekte yer alan tabloda ilgili yerlere gerekli notlar düşülmüştür. Ayrıca Bologna ${ }^{8}$ kapsamında standart bir veri paylaşımının sağlanmasına yönelik olarak üniversitelerin bölüm sayfalarında yer almayan bilgiler Bologna üzerinden elde edilmeye çalışılmıştır.

Çalışmada karşılaşılan zorluklardan bir tanesi ise çalışmaya dahil edilen bölümlerin farklı fakültelerde bulunmasıdır. Örneğin Kamu Yönetimi/ Siyaset Bilimi ve Kamu Yönetimi bölümleri kimi zaman İ.̇̇.B.F'de kimi zaman S.B.F. de yer alırken İnsan ve Toplum Bilimleri Fakültesi ise Siyaset Bilimi ve Uluslararası İlişkiler (Örn: İnbn Haldun Üniv.) bölümlerini bünyesinde taşımaktadır. Bu durumun başka bir örneğine ise Siyaset Bilimi ve Uluslararası İlişkiler bölümlerinde rastlanılmaktadır. Söz konusu bölüm (İstanbul Esenyurt Üniversitesi) İşletme ve Yönetim Bilimleri Fakültesinde kurulmuştur. Aynı bölüm Medipol Üniversitesinde ise İnsan ve Toplum Bilimleri Fakültesinde kurulmuştur. Örnekler bu şekilde çoğaltılabilir (Okan Üniversitesinde Uluslararası İlişkiler bölümü İşletme ve Yönetim Bilimleri Fakültesindedir).

Çalışmaya ilişkin olarak ortaya çıkan en önemli sorun ise incelenen derslerin bölümler bazında net olarak sınıflandırılıp sınıflandırılamayacağı sorunudur. Başka bir ifadeyle ders içeriklerine ilişkin olarak tam anlamıyla şu ders kamu yönetiminin ya da uluslararası ilişkiler bölümünün asli dersidir diyebiliyor muyuz? Bu sorunun bir varsayımdan yola

\footnotetext{
${ }^{8}$ Avrupa Birliği tarafından 2000 yılında yayınlanan Lizbon Stratejisi hedefleri çerçevesinde Türkiye 2001 yılında Bologna Sürecine dahil olmuştur.
} 
çıkarak ekarte edilmesi gerekmektedir. İlgili bölümler ile anılan dersler bölümün olmazsa olmazları olarak ifade edilebilir. Örneğin Kamu Yönetimi bölümü için İdare Hukuku, Yönetim Bilimleri, Kent ve Çevre Politikası, Kamu Yönetimine giriş dersleri bölümün iskeletini oluştururken Uluslararası İlişkiler için ise Uluslararası İlişkilere Giriş, Siyasi Tarih, Türk Dış Politikası, Uluslararası İlişkiler Teorileri, Uluslararası Hukuk gibi dersler bölümün temel derslerdir. Ancak arada kalan birkaç ders de bulunmaktadır. Bu dersler her iki bölüm tarafından programlara konulmaktadır. Özellikle siyaset bilimi ağırlıklı dersler Siyasi Düşünceler Tarihi, Türk Siyasal Hayatı, Siyaset Bilimine Giriş bu duruma örnek olarak gösterilebilir iken $A B$ ve Türkiye gibi dersler ise yine her iki bölümünde ders içeriğinde yer almaktadır. Burada yapılmak istenen çalışmanın Uluslararası İlişkiler eğitimi verilen bölümlerde iç politika, bürokrasi Türk siyasal hayatı gibi önemli sorunları görerek bir dış politika eğitimi verilmesi gerektiğidir. İlgili bölümlerin ders içerikleri incelendiğinde çalışmanın başlı̆̆ında olduğu gibi her iki disiplinin birbirinden ne derecede yaralandığı da anlaşılacaktır.

\section{Bulgular}

Elde edilen bulgular Türkiye'de devlet ve vakıf üniversitelerinde aktif olarak eğitim verilen bölüm sayılarına ilişkin bir fikir vermektedir. Siyaset Bilimi ve Kamu Yönetimi bölümlerinde uluslararası İlişkiler disiplini eğitimi ile ilgili olarak şu dersler ağırlıklı verilmektedir: Uluslararası İlişkilere Giriş, Türk Dış Politikası, Siyasi Tarih, Avrupa Birliği ve Türkiye. Uluslararası İlişkiler bölümlerinde ise Kamu Yönetim/SBKY disiplinlerine ilişkin olarak şu dersler verilmektedir: Siyaset Bilimi, Türk Siyasal Hayatı, İdare Hukuku. Seçmeli olarak ise Kamu Yönetimine Giriş, Yönetim Bilimleri, Çağdaş Yönetim Teknikleri, Kamu Politikaları. Daha detaylı bilgilere yer vermek gerekirse: Siyaset Bilimi ve Uluslararası İlişkiler bölümlerinde genel olarak kamu yönetimi derslerine, Türkiye'nin güncel yönetim sorunları ve politikalarına yeterince yer verilmediği görülmektedir. Özellikle Siyaset Bilimi ve Uluslararası İlişkiler bölümleri vakıf üniversitelerinin bünyelerinde kurulan ve revaçta olan bölümler olarak görülebilir. Ancak bu bölümlerin ders içerikleri incelendiğinde siyasete dair güncel meseleler üzerine derslere yer verildiği görülmekte, 
kamu politikaları, yönetim bilimi, kamu yönetimi gibi derslerin ise yer almadığ1 görülmektedir. Kurulan bölümlerdeki derslerin mevcut öğretim elemanı ve öğretim üyelerinin uzmanlık alanları doğrultusunda şekillendiğini söylemek mümkündür. Özellikle seçmeli ders havuzunda yer alan dersler bu fikri doğrulamaktadır. İsmi her iki disiplini de kapsayan bölümlerde (özellikle Siyaset Bilimi ve Uluslararası İlişkiler) aşırı uzmanlaşmaya gidildiği tespiti yapılabilir.

Kamu Yönetimi, Siyaset Bilimi ve Kamu Yönetimi bölümlerinin çoğunda ise uluslararası ilişkiler bölümüne ait en az bir ders bulunurken (örneğin Uluslararası İlişkilere giriş gibi) kimi zaman da bu temel derse ilave olarak Siyasi Tarih derslerinin verildiği görülmektedir. Ancak bazı bölümlerde (Örn: Bayburt Üniv. gibi) uluslararası ilişkiler disiplininden hiçbir derse yer verilmediği görülmektedir. Bu durum bir fakültede sadece Siyaset Bilimi ve Kamu Yönetimi bölümünün bulunmasıyla açıklanabilmektedir. Her iki bölümün bulunması halinde ders planları disiplinler arası olarak planlanabilmektedir. Dolayısıyla bölüm derslerinin içeriklerinin farklılaşmasında fakülte bünyesinde aktif olarak açık bulunan bölümlerin ya da uzmanlık alanı olan bir öğretim üyesinin kendi alanına yönelik bir ders açmasının önemi ortaya çıkmaktadır.

Uluslararası İlişkiler ve SBKY bölümlerinde hocaların ilgi alanlarına göre seçmeli derslerin açılması normal karşılanacak düzeyde iken kimi zaman bu bölümlerin zorunlu dersleri arasında disiplinlerin ana derslerinden ziyade yine hocaların ilgi alanları doğrultusunda derslerin konulduğu gözlemlenmektedir. Bu durum özellikle fakülte bazında ilgili bölümün açılması çabalarında alan dışı hocaların olmasından kaynaklanmaktadır. Başka bir değişle bölüm müfredatları incelendiğinde derslere göre hoca alınmadığı hocalara göre derslerin belirlendiği gözlemlenmiştir. Örneğin Altınbaş üniversitesinde SBKY bölümünde uluslararası ilişkiler ağırlıklı derslerin verildiği görülmektedir. Özellikle seçmeli ders havuzunda bu durum iyice belirginleşmektedir. Vakıf üniversitelerinde kurulan bölümlerin ağırlıklı olarak Siyaset Bilimi ve Uluslararası İlişkiler bölümü olduğu görülmektedir. Ancak bu durum ders içerikleri itibariyle siyaset bilimi veya uluslararası ilişkileri disiplininin farklı ağırlıkta verilmesi gereceğini de gözler önüne sermektedir. Vakıf üniversitelerinde istihdam edilen akademik personelin uzmanlık alanlarına göre bölümün ismi (siyaset bilimi ve uluslararası ilişkiler) ders içeriği itibariy- 
le farklılık göstermektedir. Örneğin İstanbul 29 Mayıs Üniversitesi'nde Siyaset Bilimi ve Uluslararası İlişkiler bölümü uluslararası ilişkiler ağırlıklı bir ders içeriği sunarken İstanbul Şehir Üniversitesi Siyaset Bilimi ve Uluslararası İlişkiler bölümü siyaset bilimi ağırlıklı bir ders planı koymuştur. Siyaset Bilimi adıyla kurulan bölümlerin ders içerikleri incelendiğinde ise (Örn: Işık Üniv.) derslerin Uluslararası İlişkiler ve Kamu Yönetimi derslerinden oluştuğu görülmektedir.

Tablo 2. Üniversitelerde Kamu Yönetimi, Siyaset Bilimi ve Kamu Yönetimi, Uluslararası İlişkiler, Siyaset Bilimi ve Uluslararası İlişkiler Bölümlerinin Bulunduğu Fakülteler

Fakülte İsimleri

- $\quad$ İktisadi ve İdari Bilimler Fakültesi

- $\quad$ Siyasal Bilgiler Fakültesi

- $\quad$ İktisadi İdari ve Toplum Bilimleri Fakültesi

- $\quad$ Sanat ve Sosyal Bilimler Fakültesi ${ }^{12}$

- $\quad$ Sosyal Bilimler Fakültesi ${ }^{9}$

- İktisadi İdari ve Sosyal Bilimler Fakültesi ${ }^{10}$

- İnsan ve Toplum Bilimleri Fakültesi $^{11}$

Çalışmada elde edilen sonuçlardan bir tanesi de disiplinlere yönelik öğretim programları açısından devlet ve vakıf üniversiteleri arasındaki ayrışmadır. Vakıf üniversitelerin söz konusu disiplinlerin eğitimine yönelik programlarında yer verilen derslerin devlet üniversitelerinde ne derece uygulanabileceği de önemli bir soru olarak karşımıza çıkmaktadır. Vakıf üniversitelerin eleştirilen tarafları olsa da zorunlu olan Oryantasyon dersi kapsamında birinci sınıf öğrencilerine yönelik sunulan derste öğrencilerin kaynaşması, okulun tanıtımı (kütüphane, müfredat, sosyal olanaklar vs.) mevzuatın öğretilmesi (eğitim öğretim ve disiplin yönetmeliği, yükseköğretim kanunu) önemli bir uygulama olarak kaşımıza çıkmaktadır. Devlet üniversitelerinde ise seçmeli ders havuzunda bulunan derslerin eksikliği ise göze çarpmaktadır. Yine bazı üniversitelerin (Hasan Kalyoncu Üniversitesi) seçmeli ders havuzunda Toplumsal Du-

\footnotetext{
${ }^{9}$ Özyeğin Üniversitesinde bulunmaktadır. Uluslararası Ilişkiler bölümü ile Psikoloji bölümü aynı fakültede bulunmaktadır.

${ }^{10}$ MEF Üniversitesi ve Toros Üniversitesinde bulunmaktadır.

${ }^{11}$ Yaşar Üniversitesinde bulunmaktadır.

12 Sabancı Üniversitesinde bulunmaktadır.
} 
yarlılık Dersi adında dersler bulunmaktadır. Bu gibi derslere devlet üniversitelerinde (Ege Üniversitesinde Topluma Hizmet Grupları dersi) az da olsa rastlanılmaktadır. ${ }^{13}$

\section{Sonuç}

Çalışma İnterdisipliner Eğitim Politikası Üzerine Bir Değerlendirme: Uluslararası İlişkiler ve Kamu Yönetimi Eğitimi adını taşıyarak meseleye disiplinlerarası bakıldığı algısı yaratsa da ulaşılan sonuçlar bakımdan aslında her iki disiplinin de diğer disiplinlerden nasıl yararland1ğ1/yararlanacağı üzerine odaklanılmaktadır. Örneğin her iki disiplin için Türkiye'de üniversitelerde yer verilen ders içerikleri ve programları incelendiğinde alana özgün dersler dışında multidisipliner derslere yer verildiği de görülmüştür. Dokuz Eylül Üniversitesi Uluslararası İlişkiler bölümü ders içeriğinde Sinemada Uluslararası İlişkiler, İş Hayatında Kadın, Sosyal Sorumluluk Projesi gibi dersler disiplinlerin eksik kalan yönlerini tamamlamaktadır. Bu tür derslerin diğer bölümlere uyarlanmış hallerinin verilmesi halinde bölümlere karşı olan bakış açısı değişecek ve öğrencilerin lisans programları da zenginleşecektir. Diğer taraftan uluslararası ilişkiler disiplininde işlenen güvenlik konusu son yıllarda önemli bir yer edinmiş ve Kamu Yönetimi Sempozyumunun (Gaziantep) teması olarak açılanmıştır. Yeni açılan SBKY bölümlerinde özellikle İİBF den sıyrılma çalışmaları düşünüldügüunde (eğitim dilinin İngilizce verilme isteği ile birlikte) alan dışı hocaların bölümün yükünü sırtlanmak zorunda olduğu görülmektedir. Aynı durum Uluslararası İlişkiler bölümü için de geçerlidir. Örneğin İngilizce eğitim için uluslararası ilişkiler bölümüne alınan hocaların Amerikan Dili ve Edebiyatı, Latin Dilleri gibi aslında mütercim tercümanlık bölümü için istihdam edilen kişilerden oluştuğu görülmekte bu durum disiplinin öğretilmesi açısından birtakım problemlere yol açmaktadır. Yan dalların üzerine kurulan bölümler asıl amaçtan (yani bölüm derslerini veren uzman hocalar) uzaklaşarak bölümün eğitim politikasına doğrudan etki etmektedir. Dolayısıyla gerek

\footnotetext{
${ }^{13}$ Devlet üniversitelerinin bazılarında (Hacettepe, Hatay Mustafa Kemal Üniversitesi, Inönü Üniversitesi) Kamu Yönetimi/Siyaset Bilimi ve Kamu Yönetimi bölümlerinde Denetimli Serbestlik, Çevresel Etki Değerlendirmesi gibi derslerin bulunması ders çeşitliliğine yapılan katkııı göstermektedir.
} 
SBKY gerekse Uluslararası ilişkiler bölüleri kurulurken uzmanlık alanları doğrulusunda hocaların istihdam edilmesi büyük önem arz etmektedir. Bazı vakıf üniversitelerinin (Beykent Üniv gibi) ilgili bölümlerinde Oryantasyon derslerine yer verildiği görülmektedir. Böylelikle öğrencinin üniversitenin olanaklarını (kütüphane yemekhane sosyal alanları) göreceği öğrenci disiplini yönetmeliği ve YÖK kanunu anlatılmakta ve okula uyum sorunu yaşamayacağı düşünülmektedir.

EK1: Türkiye'de Bölümlerin Üniversite Bazında Dă̆lımı ${ }^{1}$

\begin{tabular}{|c|c|c|c|c|c|}
\hline & & $\begin{array}{l}\text { Uluslararası } \\
\text { İlişkiler }\end{array}$ & $\begin{array}{l}\text { Kamu } \\
\text { Yöneti- } \\
\text { mi }\end{array}$ & $\begin{array}{l}\text { Siyaset } \\
\text { Bilimi Ve } \\
\text { Uluslararası } \\
\text { İlişkiler }\end{array}$ & $\begin{array}{l}\text { Siyaset } \\
\text { Bilimi Ve } \\
\text { Kamu } \\
\text { Yönetimi }\end{array}$ \\
\hline 1 & $\begin{array}{l}\text { Abdullah Gül } \\
\text { Üniversitesi }^{2}\end{array}$ & & & & \\
\hline 2 & $\begin{array}{l}\text { Acıbadem Mehmet Ali } \\
\text { Aydınlar Üniversitesi }{ }^{3}\end{array}$ & & & & \\
\hline 3 & $\begin{array}{l}\text { Adana Bilim Ve Teknoloji } \\
\text { Üniversitesi }^{4}\end{array}$ & & & & $x$ \\
\hline 4 & Adıyaman Üniversitesi & & $X^{5}$ & & \\
\hline 5 & $\begin{array}{l}\text { Afyon Kocatepe } \\
\text { Üniversitesi }\end{array}$ & & & & $X^{6}$ \\
\hline 6 & $\begin{array}{l}\text { Afyonkarahisar Sağlık } \\
\text { Bilimleri Üniversitesi }\end{array}$ & & & & \\
\hline 7 & $\begin{array}{l}\text { A ğrı İbrahim Çeçen } \\
\text { Üniversitesi }\end{array}$ & $\mathrm{X}^{8}$ & & & $X^{9}$ \\
\hline 8 & Akdeniz Üniversitesi & $\mathrm{X}^{10}$ & & & $\mathrm{X}^{11}$ \\
\hline 9 & Aksaray Üniversitesi & $\mathrm{X}^{12}$ & & & $\mathrm{X}^{13}$ \\
\hline 10 & $\begin{array}{l}\text { Alanya Alaaddin } \\
\text { Keykubat Üniversitesi }{ }^{14}\end{array}$ & & & & \\
\hline 11 & $\begin{array}{l}\text { Alanya Hamdullah } \\
\text { Emin Paşa Üniversitesi }^{15}\end{array}$ & & & & \\
\hline 12 & Altınbaş Üniversitesi & $\mathrm{X}^{16}$ & & & $\mathrm{X}^{17}$ \\
\hline 13 & Amasya Üniversitesi ${ }^{18}$ & & & & \\
\hline 14 & Anadolu Üniversitesi ${ }^{19}$ & & & & \\
\hline 15 & $\begin{array}{l}\text { Anka Teknoloji } \\
\text { Üniversitesi }^{20} \\
\end{array}$ & & & & \\
\hline 16 & $\begin{array}{l}\text { Ankara Hacı Bayram } \\
\text { Veli Üniversitesi }\end{array}$ & & & & $\mathrm{X}^{21}$ \\
\hline 17 & $\begin{array}{l}\text { Ankara Medipol } \\
\text { Üniversitesi }^{22} \\
\end{array}$ & & & & \\
\hline 18 & $\begin{array}{l}\text { Ankara Müzik Ve Güzel } \\
\text { Sanatlar Üniversitesi }\end{array}$ & & & & \\
\hline 19 & $\begin{array}{l}\text { Ankara Sosyal } \\
\text { Bilimler Üniversitesi }\end{array}$ & $\mathrm{X}^{23}$ & - & - & $\mathrm{X}^{24}$ \\
\hline
\end{tabular}




\begin{tabular}{|c|c|c|c|c|c|}
\hline 20 & Ankara Üniversitesi & $X^{25}$ & - & - & $X^{26}$ \\
\hline 21 & $\begin{array}{l}\text { Ankara Yıldırım } \\
\text { Beyazıt Üniversitesi }\end{array}$ & $\mathrm{X}^{27}$ & - & - & $X^{28}$ \\
\hline 22 & Antalya Akev Üniversitesi & - & - & - & - \\
\hline 23 & Antalya Bilim Üniversitesi & - & - & $\mathrm{X}^{29}$ & - \\
\hline 24 & Ardahan Üniversitesi & $\mathrm{X}^{30}$ & - & - & $X^{31}$ \\
\hline 25 & Artvin Çoruh Üniversitesi & - & - & - & $\mathrm{X}^{32}$ \\
\hline 26 & $\begin{array}{l}\text { Ataşehir Adıgüzel } \\
\text { Meslek Yüksekokulu }\end{array}$ & & & & \\
\hline 27 & Atatürk Üniversitesi & $\mathrm{X}^{33}$ & $\mathrm{X}^{34}$ & - & - \\
\hline 28 & Atılım Üniversitesi & $\mathrm{X}^{35}$ & - & - & $\mathrm{X}^{36}$ \\
\hline 29 & Avrasya Üniversitesi & $X$ & - & - & $X^{37}$ \\
\hline 30 & $\begin{array}{l}\text { Avrupa Meslek } \\
\text { Yüksekokulu }\end{array}$ & - & - & - & \\
\hline 31 & $\begin{array}{l}\text { Aydın Adnan Menderes } \\
\text { Üniversitesi }^{38}\end{array}$ & $\mathrm{X}^{39} \mathrm{Y}^{40}$ & $X^{41}$ & - & $X^{42}$ \\
\hline 32 & Bahçeşehir Üniversitesi & - & - & $\mathrm{X}^{43}$ & \\
\hline 33 & Balıkesir Üniversitesi & - & - & - & $X^{44}$ \\
\hline 34 & $\begin{array}{l}\text { Bandırma Onyedi } \\
\text { Eylül Üniversitesi }\end{array}$ & $X^{45}$ & - & - & $X^{46}$ \\
\hline 35 & Bartın Üniversitesi & - & - & - & $X^{47}$ \\
\hline 36 & Başkent Üniversitesi & - & - & $\mathrm{X}^{48}$ & - \\
\hline 37 & Batman Üniversitesi ${ }^{49}$ & $X$ & - & - & $X$ \\
\hline 38 & Bayburt Üniversitesi & - & - & - & $\mathrm{X}^{50}$ \\
\hline 39 & Beykent Üniversitesi & $\mathrm{X}^{51}$ & - & - & $X^{52}$ \\
\hline 40 & Beykoz Üniversitesi & - & - & $\mathrm{X}^{53}$ & - \\
\hline 41 & $\begin{array}{l}\text { Bezmi Alem Vakıf } \\
\text { Üniversitesi }^{54}\end{array}$ & & & & \\
\hline 42 & $\begin{array}{l}\text { Bilecik Şeyh Edebali } \\
\text { Üniversitesi }\end{array}$ & - & - & - & $X^{55}$ \\
\hline 43 & Bingöl Üniversitesi & - & - & - & $X^{56}$ \\
\hline 44 & Biruni Üniversitesi ${ }^{57}$ & & & & \\
\hline 45 & Biltlis Eren Üniversitesi & $X^{58}$ & $X^{59}$ & - & - \\
\hline 46 & Boğaziçi Üniversitesi & - & - & $X^{60}$ & - \\
\hline 47 & $\begin{array}{l}\text { Bolu Abant İzzet } \\
\text { Baysal Üniversitesi }\end{array}$ & $X^{61}$ & $X^{62}$ & - & - \\
\hline 48 & $\begin{array}{l}\text { Burdur Mehmet Akif } \\
\text { Ersoy Üniversitesi }\end{array}$ & - & - & - & $X^{63}$ \\
\hline 49 & Bursa Teknik Üniversitesi & $X^{64}$ & - & $X^{65}$ & - \\
\hline 50 & Bursa Uludağ Üniversitesi & $X^{66}$ & - & - & $X^{67}$ \\
\hline 51 & Çă̆ Üniversitesi & - & - & - & - \\
\hline 52 & $\begin{array}{l}\text { Çanakale } 18 \text { Mart } \\
\text { Üniversitesi }^{68}\end{array}$ & $X^{69}$ & $X^{70}$ & - & $X^{71}$ \\
\hline 53 & Çankaya Üniversitesi & - & - & $\mathrm{X}^{72}$ & - \\
\hline 54 & $\begin{array}{l}\text { Çankırı Karatekin } \\
\text { Üniversitesi }\end{array}$ & $X^{73}$ & - & - & $X^{74}$ \\
\hline 55 & Çukurova Üniversitesi & - & - & $\mathrm{X}^{75}$ & - \\
\hline 56 & Dicle Üniversitesi & - & - & - & $X^{76}$ \\
\hline
\end{tabular}


İnterdisipliner Eğitim Politikası Üzerine Bir Değerlendirme: Uluslararası İlişkiler ve Kamu Yönetimi Eğitimi

\begin{tabular}{|c|c|c|c|c|c|}
\hline 57 & Doğuş Üniversitesi & $X^{77}$ & - & - & $X^{78}$ \\
\hline 58 & $\begin{array}{l}\text { Dokuz Eylül } \\
\text { Üniversitesi }^{79}\end{array}$ & $\mathrm{X}^{80}$ & $X^{81}$ & - & - \\
\hline 59 & Düzce Üniversitesi & $X^{82}$ & - & - & - \\
\hline 60 & Ege Üniversitesi & $\mathrm{X}^{83}$ & - & - & - \\
\hline 61 & Erciyes Üniversitesi & $\mathrm{X}^{84}$ & - & $X$ & $X$ \\
\hline 62 & Erzincan B.Y. Üniversitesi & - & - & - & $\mathrm{X}^{85}$ \\
\hline 63 & $\begin{array}{l}\text { Erzurum Teknik } \\
\text { Üniversitesi }\end{array}$ & - & - & - & - \\
\hline 64 & $\begin{array}{l}\text { Eskişehir Osmangazi } \\
\text { Üniversitesi }\end{array}$ & $X^{86}$ & - & - & $\mathrm{X}^{87}$ \\
\hline 65 & $\begin{array}{l}\text { Eskişehir Teknik } \\
\text { Üniversitesi }\end{array}$ & - & - & - & - \\
\hline 66 & Fsm Vakıf Üniversitesi & - & - & - & - \\
\hline 67 & $\begin{array}{l}\text { Fenerbahçe } \\
\text { Üniversitesi }^{88}\end{array}$ & - & - & - & - \\
\hline 68 & Firat Üniversitesi & - & - & - & $\mathrm{X}^{89}$ \\
\hline 69 & Galatasaray Üniversitesi & $X^{90}$ & $\mathrm{X}^{14}$ & - & - \\
\hline 70 & Gazi Üniversitesi & - & - & - & - \\
\hline 71 & $\begin{array}{l}\text { Gaziiantep İslam Bilim Ve } \\
\text { Teknik Üniversitesi }\end{array}$ & - & - & - & - \\
\hline 72 & Gaziantep Üniversitesi & $X^{91}$ & - & - & $X^{92}$ \\
\hline 73 & $\begin{array}{l}\text { Gebze Teknik } \\
\text { Üniversitesi }\end{array}$ & - & - & - & - \\
\hline 74 & Giresun Üniversitesi & $X^{93}$ & - & - & $X^{94}$ \\
\hline 75 & Gümüşhane Üniversitesi & $X^{95}$ & - & - & $X^{96}$ \\
\hline 76 & Hacettepe Üniversitesi & $X^{97}$ & - & - & $X^{98}$ \\
\hline 77 & Hakkâri Üniversitesi & - & - & $X^{99}$ & - \\
\hline 78 & Haliç Üniversitesi & - & - & $\mathrm{X}^{100}$ & - \\
\hline 79 & Harran Üniversitesi & - & $\mathrm{X}^{101}$ & - & - \\
\hline 80 & $\begin{array}{l}\text { Hasan Kalyomcu } \\
\text { Üniversitesi }\end{array}$ & - & - & $X^{102}$ & - \\
\hline 81 & $\begin{array}{l}\text { Hatay Mustafa } \\
\text { Kemal Üniversitesi }\end{array}$ & - & - & - & $X^{103}$ \\
\hline 82 & Hitit Üniversitesi & - & - & - & $\mathrm{X}^{104}$ \\
\hline 83 & Iğdır Üniversitesi & - & - & - & $X^{105}$ \\
\hline 84 & $\begin{array}{l}\text { Isparta Uygulamalı } \\
\text { Bilimler Üniversitesi } \\
\end{array}$ & - & - & - & - \\
\hline 85 & Işık Üniversitesi ${ }^{15}$ & $X^{106}$ & - & - & - \\
\hline 86 & $\begin{array}{l}\text { İbni-İ Haldun } \\
\text { Üniversitesi }\end{array}$ & - & - & $X^{107}$ & - \\
\hline 87 & $\begin{array}{l}\text { İhsan Doğramacı } \\
\text { Bilkent Üniversitesi }\end{array}$ & $X^{108}$ & - & - & $X^{109}$ \\
\hline
\end{tabular}

${ }^{14}$ Bölüm, Siyaset Bilimi olarak geçmektedir. Idare Hukuku, Kentleşme, Kamu Yönetimi derslerinin bulunduğu bölüm Fransızca okutulmaktadır.

15 Siyaset Bilimi bölümü bulunmaktadır. Kamu Politikası Yerel Yönetimler Türk Dış Politikası gibi dersler bulunmaktadır. 


\begin{tabular}{|c|c|c|c|c|c|}
\hline 88 & İnönü Üniversitesi & $X^{110}$ & - & - & $X^{111}$ \\
\hline 89 & $\begin{array}{l}\text { İskenderun Teknik } \\
\text { Üniversitesi }\end{array}$ & - & - & - & - \\
\hline 90 & İstanbul Arel Üniversitesi & $X^{112}$ & - & - & $X^{113}$ \\
\hline 91 & $\begin{array}{l}\text { İstanbul Atlas } \\
\text { Üniversitesi } \\
\end{array}$ & - & - & - & - \\
\hline 92 & $\begin{array}{l}\text { İstanbul Aydın } \\
\text { Üniversitesi }\end{array}$ & - & - & $\mathrm{X}^{114}$ & - \\
\hline 93 & $\begin{array}{l}\text { İstanbul Ayvansaray } \\
\text { Üniversitesi }\end{array}$ & - & - & - & - \\
\hline 94 & $\begin{array}{l}\text { İstanbul Bilgi } \\
\text { Üniversitesi }^{16}\end{array}$ & $\mathrm{X}^{115}$ & - & - & - \\
\hline 95 & $\begin{array}{l}\text { İstanbul Demiroğlu } \\
\text { Bilim Üniversitesi }\end{array}$ & - & - & - & - \\
\hline 96 & $\begin{array}{l}\text { İstanbul Esenyurt } \\
\text { Üniversitesi }\end{array}$ & - & - & $\mathrm{X}^{116}$ & - \\
\hline 97 & $\begin{array}{l}\text { İstanbul Gedik } \\
\text { Üniversitesi }\end{array}$ & $\mathrm{X}^{117}$ & - & - & $\mathrm{X}^{118}$ \\
\hline 98 & $\begin{array}{l}\text { İstanbul Gelişim } \\
\text { Üniversitesi }\end{array}$ & - & - & $\mathrm{X}^{119}$ & $X^{120}$ \\
\hline 99 & İstanbul Kent Üniversitesi & - & - & - & $X^{121}$ \\
\hline 100 & $\begin{array}{l}\text { İstanbul Kültür } \\
\text { Üniversitesi }\end{array}$ & $X^{122}$ & - & - & - \\
\hline 101 & $\begin{array}{l}\text { İstanbul Medeniyet } \\
\text { Üniversitesi }\end{array}$ & $X^{123}$ & - & - & $X^{124}$ \\
\hline 102 & $\begin{array}{l}\text { İstanbul Medipol } \\
\text { Üniversitesi }\end{array}$ & - & - & $\mathrm{X}^{125}$ & $X^{126}$ \\
\hline 103 & $\begin{array}{l}\text { İstanbul Okan } \\
\text { Üniversitesi }\end{array}$ & $X^{127}$ & - & - & - \\
\hline 104 & $\begin{array}{l}\text { İstanbul Rumeli } \\
\text { Üniversitesi }\end{array}$ & $X^{128}$ & - & - & $X^{129}$ \\
\hline 105 & $\begin{array}{l}\text { İstanbul Sabahattin } \\
\text { Zaim Üniversitesi }\end{array}$ & - & - & $\mathrm{X}^{130}$ & - \\
\hline 106 & İstanbul Şehir Üniversitesi & - & - & $\mathrm{X}^{131}$ & - \\
\hline 107 & $\begin{array}{l}\text { İstanbul Teknik } \\
\text { Üniversitesi }\end{array}$ & - & - & - & - \\
\hline 108 & $\begin{array}{l}\text { İstanbul Ticaret } \\
\text { Üniversitesi }\end{array}$ & - & - & - & - \\
\hline 109 & İstanbul Üniversitesi & - & - & $\mathrm{X}^{132}$ & $X^{133}$ \\
\hline 110 & $\begin{array}{l}\text { İstanbul Üniversitesi- } \\
\text { Cerrahpaşa }\end{array}$ & - & - & - & - \\
\hline 111 & $\begin{array}{l}\text { İstanbul Yeni Yüzyıl } \\
\text { Üniversitesi }\end{array}$ & - & - & $\mathrm{X}^{134}$ & - \\
\hline 112 & $\begin{array}{l}\text { İstanbul } 29 \text { Mayıs } \\
\text { Üniversitesi }\end{array}$ & - & - & $\mathrm{X}^{135}$ & - \\
\hline
\end{tabular}

16 Siyaset Bilimi bölümü bulunmaktadır. Uluslararası ilişkiler, Siyasi ve Diplomatik Tarih, Türk Dış Politikası, TDP'de Güncel Sorunlar dersleri verilmektedir. 
İnterdisipliner Eğitim Politikası Üzerine Bir Değerlendirme: Uluslararası İlişkiler ve Kamu Yönetimi Eğitimi

\begin{tabular}{|c|c|c|c|c|c|}
\hline 113 & İstinye Üniversitesi & $\mathrm{X}^{136}$ & - & - & $\mathrm{X}^{137}$ \\
\hline 114 & İzmir Bakırçay Üniversitesi & - & - & - & - \\
\hline 115 & $\begin{array}{l}\text { İzmir Demokrasi } \\
\text { Üniversitesi }\end{array}$ & $\mathrm{X}^{138}$ & - & - & $\mathrm{X}^{139}$ \\
\hline 116 & $\begin{array}{l}\text { İzmir Ekonomi } \\
\text { Üniversitesi }\end{array}$ & - & - & $X^{140}$ & - \\
\hline 117 & $\begin{array}{l}\text { İzmir Kâtip Çelebi } \\
\text { Üniversitesi }\end{array}$ & $\mathrm{X}^{141}$ & - & - & $\mathrm{X}^{142}$ \\
\hline 118 & $\begin{array}{l}\text { İzmir Tınaztepe } \\
\text { Üniversitesi }\end{array}$ & - & - & - & - \\
\hline 119 & $\begin{array}{l}\text { İzmir Yüksek } \\
\text { Teknoloji Enstitüsü }\end{array}$ & - & - & - & - \\
\hline 120 & Kadir Has Üniversitesi & $\mathrm{X}^{143}$ & - & - & $\mathrm{X}^{144}$ \\
\hline 121 & Kafkas Üniversitesi & - & - & $\mathrm{X}^{145}$ & $\mathrm{X}^{146}$ \\
\hline 122 & $\begin{array}{l}\text { Kahramanmaraş } \\
\text { İstiklal Üniversitesi }\end{array}$ & - & - & - & - \\
\hline 123 & $\begin{array}{l}\text { Kahramanmaraş } \\
\text { Sütçü İmam Üniversitesi }\end{array}$ & - & $\mathrm{X}^{147}$ & $X^{148}$ & - \\
\hline 124 & Kapadokya Üniversitesi & - & - & $X^{149}$ & $\mathrm{X}^{150}$ \\
\hline 125 & Karabük Üniversitesi & $X$ & - & - & $\mathrm{X}^{151}$ \\
\hline 126 & $\begin{array}{l}\text { Karadeniz Teknik } \\
\text { Üniversitesi } \\
\end{array}$ & $\mathrm{X}^{152}$ & $\mathrm{X}^{153}$ & - & - \\
\hline 127 & $\begin{array}{l}\text { Karamanoğlu Mehmet } \\
\text { Bey Üniversitesi }\end{array}$ & - & - & $X^{154}$ & $\mathrm{X}^{155}$ \\
\hline 128 & Kastamonu Üniversitesi & $\mathrm{X}^{156}$ & - & - & $\mathrm{X}^{157}$ \\
\hline 129 & Kayseri Üniversitesi & - & - & - & - \\
\hline 130 & Kırıkkale Üniversitesi & $\mathrm{X}^{158}$ & - & - & $\mathrm{X}^{159}$ \\
\hline 131 & Kırklareli Üniversitesi & $\mathrm{X}^{160}$ & $\mathrm{X}^{161}$ & - & - \\
\hline 132 & $\begin{array}{l}\text { Kurşehir Ahi Evran } \\
\text { Üniversitesi }\end{array}$ & $\mathrm{X}^{162}$ & - & - & $\mathrm{X}^{163}$ \\
\hline 133 & Kilis 7 Aralık Üniversitesi & - & - & - & $\mathrm{X}^{164}$ \\
\hline 134 & Kocaeli Üniversitesi & $\mathrm{X}^{165}$ & - & - & $\mathrm{X}^{166}$ \\
\hline 135 & Koç Üniversitesi & $\mathrm{X}^{167}$ & - & - & - \\
\hline 136 & $\begin{array}{l}\text { Konya Gıda Ve Tarım } \\
\text { Üniversitesi }\end{array}$ & - & - & - & - \\
\hline 137 & Konya Teknik Üniversitesi & - & - & - & - \\
\hline 138 & Kto Karatay Üniversitesi & - & - & - & - \\
\hline 139 & $\begin{array}{l}\text { Kütahya Dumlupınar } \\
\text { Üniversitesi }\end{array}$ & - & $\mathrm{X}^{168}$ & $X^{169}$ & - \\
\hline 140 & $\begin{array}{l}\text { Kütahya Sağlık } \\
\text { Bilimleri Üniversitesi } \\
\end{array}$ & - & - & - & - \\
\hline 141 & $\begin{array}{l}\text { Lokman Hekim } \\
\text { Üniversitesi }\end{array}$ & - & - & - & - \\
\hline 142 & $\begin{array}{l}\text { Malatya Turgut Özal } \\
\text { Üniversitesi }\end{array}$ & - & - & - & - \\
\hline 143 & Maltepe Üniversitesi & - & - & $\mathrm{X}^{170}$ & - \\
\hline 144 & $\begin{array}{l}\text { Manisa Celala Bayar } \\
\text { Üniversitesi }\end{array}$ & - & $X^{171}$ & $X^{172}$ & - \\
\hline
\end{tabular}




\begin{tabular}{|c|c|c|c|c|c|}
\hline 145 & $\begin{array}{l}\text { Mardin Artuklu } \\
\text { Üniversitesi }\end{array}$ & - & - & $X^{173}$ & - \\
\hline 146 & Marmara Üniversitesi ${ }^{17}$ & $\mathrm{X}^{174}$ & - & $\mathrm{X}^{175}$ & $\mathrm{X}^{176}$ \\
\hline 147 & Mef Üniversitesi & - & - & $X^{177}$ & - \\
\hline 148 & Mersin Üniversitesi & $\mathrm{X}^{178}$ & $\mathrm{X}^{179}$ & - & - \\
\hline 149 & $\begin{array}{l}\text { Mimar Sinan Güzel } \\
\text { Sanatlar Üniversitesi }\end{array}$ & - & - & - & - \\
\hline 150 & $\begin{array}{l}\text { Muğla Sitk1 Koçman } \\
\text { Üniversitesi }\end{array}$ & - & $\mathrm{X}^{180}$ & $X^{181}$ & - \\
\hline 151 & Munzur Üniversitesi & - & - & - & $X^{182}$ \\
\hline 152 & $\begin{array}{l}\text { Muş Alparslan } \\
\text { Üniversitesi }\end{array}$ & - & - & - & $X^{183}$ \\
\hline 153 & $\begin{array}{l}\text { Necmettin Erbakan } \\
\text { Üniversitesi }\end{array}$ & $\mathrm{X}^{184}$ & - & - & $X^{185}$ \\
\hline 154 & $\begin{array}{l}\text { Nevşehir Hacı Bektaşı } \\
\text { Veli Üniversitesi }\end{array}$ & $\mathrm{X}^{186}$ & $\mathrm{X}^{187}$ & - & - \\
\hline 155 & $\begin{array}{l}\text { Niğde Ömer } \\
\text { Halisdemir Üniversitesi }\end{array}$ & - & $\mathrm{X}^{188}$ & $X^{189}$ & - \\
\hline 156 & Nişantaşı Üniversitesi & $\mathrm{X}^{190}$ & - & - & $\mathrm{X}^{191}$ \\
\hline 157 & $\begin{array}{l}\text { Nuh Naci Yazgan } \\
\text { Üniversitesi }\end{array}$ & - & - & - & $X^{192}$ \\
\hline 158 & $\begin{array}{l}\text { Ondokuz Mayıs } \\
\text { Üniversitesi }\end{array}$ & - & - & $X^{193}$ & $X^{194}$ \\
\hline 159 & Ordu Üniversitesi & - & - & - & $X^{195}$ \\
\hline 160 & $\begin{array}{l}\text { Ortadoğu Teknik } \\
\text { Üniversitesi }\end{array}$ & $X$ & - & - & $X$ \\
\hline 161 & $\begin{array}{l}\text { Osmaniye Korkut Ata } \\
\text { Üniversitesi }\end{array}$ & $\mathrm{X}^{196}$ & - & - & $\mathrm{X}^{197}$ \\
\hline 162 & Ostim Teknik Üniversitesi & - & - & - & - \\
\hline 163 & Özyeğin Üniversitesi & $\mathrm{X}^{198}$ & - & - & - \\
\hline 164 & Pamukkale Üniversitesi & - & - & - & $\mathrm{X}^{199}$ \\
\hline 165 & Piri Reis Üniversitesi & - & - & - & - \\
\hline 166 & $\begin{array}{l}\text { Recep Tayyip } \\
\text { Erdoğan Üniversitesi }\end{array}$ & $X^{200}$ & - & - & $X^{201}$ \\
\hline 167 & Sabancı Üniversitesi ${ }^{18}$ & $X^{202}$ & - & - & - \\
\hline 168 & $\begin{array}{l}\text { Sağlık Bilimleri } \\
\text { Üniversitesi } \\
\end{array}$ & - & - & - & - \\
\hline 169 & $\begin{array}{l}\text { Sakarya Uygulamalı } \\
\text { Bilimler Üniversitesi }\end{array}$ & - & - & - & - \\
\hline 170 & Sakarya Üniversitesi & $X^{203}$ & - & - & $X^{204}$ \\
\hline 171 & Samsun Üniversitesi & - & - & - & - \\
\hline 172 & Sanko Üniversitesi & - & - & - & - \\
\hline 173 & Selçuk Üniversitesi & $X^{205}$ & - & - & $X^{206}$ \\
\hline 174 & $\begin{array}{l}\text { Semerkand Biim Ve } \\
\text { Teknoloji Üniversitesi }\end{array}$ & - & - & - & - \\
\hline
\end{tabular}

17 Siyasal Bilgiler Fakültesinde Yerel Yönetimler bölümü bulunmaktadır.

${ }^{18}$ Sanat ve Sosyal Bilimler Fakültesinde (SSBF) Siyaset Bilimi bölümü bulunmaktadır. 
İnterdisipliner Eğitim Politikası Üzerine Bir Değerlendirme: Uluslararası İlişkiler ve Kamu Yönetimi Eğitimi

\begin{tabular}{|c|c|c|c|c|c|}
\hline 175 & Siirt Üniversitesi & - & - & - & - \\
\hline 176 & Sinop Üniversitesi & - & - & - & $\mathrm{X}^{207}$ \\
\hline 177 & $\begin{array}{l}\text { Sivas Bilim Ve } \\
\text { Teknoloji Üniversitesi }\end{array}$ & - & - & - & - \\
\hline 178 & $\begin{array}{l}\text { Sivas Cumhuriyet } \\
\text { Üniversitesi }\end{array}$ & - & $X^{208}$ & - & - \\
\hline 179 & $\begin{array}{l}\text { Süleyman Demirel } \\
\text { Üniversitesi }\end{array}$ & $X^{209}$ & - & - & $\mathrm{X}^{210}$ \\
\hline 180 & Şırnak Üniversitesi & - & - & - & $\mathrm{X}^{211}$ \\
\hline 181 & Tarsus Üniversitesi & - & - & - & - \\
\hline 182 & Ted Üniversitesi & - & - & $\mathrm{X}^{212}$ & - \\
\hline 183 & $\begin{array}{l}\text { Tekirdağ Namık } \\
\text { Kemal Üniversitesi }\end{array}$ & $X^{213}$ & - & - & $\mathrm{X}^{214}$ \\
\hline 184 & $\begin{array}{l}\text { Tobb Ekonomi Ve } \\
\text { Teknoloji Üniversitesi }\end{array}$ & - & - & $X^{215}$ & - \\
\hline 185 & $\begin{array}{l}\text { Tokat Gaziosmanpaşa } \\
\text { Üniversitesi }\end{array}$ & - & $\mathrm{X}^{216}$ & $\mathrm{X}^{217}$ & - \\
\hline 186 & Toros Üniversitesi & - & - & - & - \\
\hline 187 & Trabzon Üniversitesi & - & - & - & - \\
\hline 188 & Trakya Üniversitesi & $\mathrm{X}^{218}$ & $X^{219}$ & - & - \\
\hline 189 & $\begin{array}{l}\text { Türk Hava Kurumu } \\
\text { Üniversitesi }\end{array}$ & - & - & - & - \\
\hline 190 & Türk-Alman Üniversitesi & - & - & $\mathrm{X}^{220}$ & - \\
\hline 191 & $\begin{array}{l}\text { Türkiye Uluslararası İslam } \\
\text { Bilim Ve Teknoloji } \\
\text { Üniversitesi }\end{array}$ & - & - & - & - \\
\hline 192 & $\begin{array}{l}\text { Türk Japon Bilim Ve } \\
\text { Teknoloji Üniversitesi }\end{array}$ & - & - & - & - \\
\hline 193 & Ufuk Üniversitesi & - & - & $\mathrm{X}^{221}$ & - \\
\hline 194 & Uşak Üniversitesi ${ }^{19}$ & - & $\mathrm{X}^{222}$ & - & - \\
\hline 195 & Üsküdar Üniversitesi & - & - & $X^{223}$ & - \\
\hline 196 & $\begin{array}{l}\text { Van Yüzüncü Yıl } \\
\text { Üniversitesi }\end{array}$ & $X^{224}$ & $\mathrm{X}^{225}$ & - & - \\
\hline 197 & Yalova Üniversitesi & $X^{226}$ & & - & \\
\hline 198 & Yaşar Üniversitesi & $\mathrm{X}^{227}$ & - & - & - \\
\hline 199 & Yeditepe Üniversitesi & - & $\mathrm{X}^{228}$ & $X^{229}$ & - \\
\hline 200 & Yıldız Teknik Üniversitesi & & & & \\
\hline 201 & Yozgat Bozok Üniversitesi & $\mathrm{X}^{230}$ & - & - & $X^{231}$ \\
\hline 202 & Yüksek İhtisas Üniversitesi & - & - & - & - \\
\hline 203 & $\begin{array}{l}\text { Zonguldak Bülent } \\
\text { Ecevit Üniversitesi }\end{array}$ & - & - & - & $\mathrm{X}^{232}$ \\
\hline
\end{tabular}

\footnotetext{
${ }^{19}$ Siyaset Bilimi ve Uluslararası İlişkiler bölümü öğrenci alımına başlamamıştır.
} 
EXTENDED ABSTRACT

\title{
An Evaluation on Interdisciplinary Education Policy: International Relations and Public Administration Education
}

\author{
* \\ Merve Mescioğlu Fedai - Recep Fedai \\ Ankara University - Çanakkale Onsekiz Mart University
}

The study was prepared by an active open and Public Administration course made and subjected to content analysis of lesson plans and course contents of the International Relations department of state and private universities in Turkey. However, PSPA and Political Science and International Relations departments were also included in the study. Accordingly, International Relations and public administration courses and course contents were analyzed. As a result of the analyzes, it will be determined where the differentiation originates from, and an assessment will be made on how to spread the applications that are thought to be beneficial by providing original applications related to the departments. The study focuses on how the disciplines of public administration and international relations are placed in the course contents and plans for the said departments of the universities. Whether the course planning is based on academic priorities or a different priority will be determined. In this context, the study reflects the theoretical implications of the theoretical discussion by examining the degree to which the two disciplines take part in each other's program by looking at the curriculum of the undergraduate departments of international relations and public administration. In addition to this, it is aimed that the study will become a guide for universities in terms of preparation of academic program.

The findings obtained from this study gives an idea of the number of active education department in the state and private universities in Turkey. Political Science and International Relations discipline regarding these courses is mainly given training in Public Administration: Introduction to International Relations, Turkish Foreign Policy, Political History, European Union and Turkey. In the International Relations de- 
partments, the following courses are given related to the disciplines of Public Administration / PSPA, Political Science, Turkish Political Life, Administrative Law. Elective: Introduction to Public Administration, Management Sciences, Contemporary Management Techniques, Public Policies. To give place to more detailed information: Political Science and the general public management course in International Relations Department, Turkey is seen not been provided to the current management issues and policies. Particularly, the departments of Political Science and International Relations can be seen as the most popular and established departments within the foundation universities. However, when the course contents of these departments are examined, it is seen that there are courses on current issues related to politics, and courses such as public policies, management science and public administration do not take place. It is possible to say that the courses in the established departments are shaped in line with the expertise areas of the current instructors and faculty members. Especially the courses in the elective pool confirm this idea. It can be determined that excessive specialization is made in the departments which include both disciplines. In most of the departments of Public Administration, Political Science and Public Administration, there is at least one course related to the Department of International Relations, such as Introduction to International Relations. However, it is seen that some courses do not include any courses from the discipline of international relations.

One of the results obtained in this study is the distinction between state and foundation universities in terms of education programs for disciplines. It is also an important question as to what extent the courses given in the programs of foundation universities for the education of these disciplines can be applied in public universities. Even though the foundation has criticized sides of the universities, the integration of the students, the promotion of the school (library, curriculum, social facilities, etc.) and the teaching of the legislation (education and disciplinary regulations, higher education law) are an important practice in the course offered to first-year students within the scope of the mandatory Orientation course. In the state universities, the lack of courses in the elective pool is noteworthy. Although the study creates the perception of interdisciplinary approach it focuses on how both disciplines benefit / 
benefit from other disciplines. For example, course content and program given university places in Turkey for both disciplines was observed that given the multidisciplinary course lessons outside the original area is examined.

\section{Kaynakça / References}

Adalı, G. (2010). Türkiye'de kamu yönetimi eğitimini yeniden düşünmek; kamu yönetimi eğitiminin günümüz Türkiye'sinde kamu kurumlarını eğitim ihtiyacını karşılama durumu. Yayımlanmamış Yüksek Lisans Tezi, Kocaeli Üniversitesi Sosyal Bilimler Enstitüsü Siyaset Bilimi ve Kamu Yönetimi Bölümü, Kocaeli.

Alkuş, O. (2000). Türkiye'de kamu yönetimi eğitimi: Üniversitelerin kamu yönetimi bölümlerinde bir uygulama (1996-1997 öğretim yıll). Yayımlanmamış Doktora Tezi, İnönü Üniversitesi Sosyal Bilimler Enstitüsü Kamu Yönetimi, Malatya.

Altan, Y., Kerman, U., ve Aktel, M. (2009). Kamu yönetiminde lisans öğretimi: Kamu yönetimi öğrencileri üzerinde bir araştırma, SDÜ Fen Edebiyat Fakültesi Sosyal Bilimler Dergisi, 20, 227-252.

Akpınar, A. (2017). Türkiye'de siyaset bilimi ve kamu yönetimi eğitimi: Eğitimistihdam ilişkisine ilişkin bir inceleme. Yayımlanmamış Yüksel Lisans Tezi, İstanbul Medeniyet Üniversitesi Sosyal Bilimler Enstitüsü Siyaset Bilimi ve Kamu Yönetimi Anabilim Dalı, İstanbul.

Anayasada Yapılan Değişikliklere Uyum Sağlanması Amacıyla Bazı Kanun ve Kanun Hükmünde Kararnamelerde Değişiklik Yapılması Hakkında Kanun Hükmünde Kararname (9 Temmuz, 2018). Resmi Gazete. (Sayı: 30743).

Bazoğlu S., D. (2005). Türkiye'de uluslararası ilişkiler çalışmalarının bilim dalı olarak gelişmesine güncel ve tarihsel bir bakış. Uluslararası İlişkiler Dergisi, 2(6), 30-53.

Dedeoğlu, B. (2005). Türkiye'de uluslararası ilişkiler çalışmaları ve eğitimi çalıştayı (16-17 Nisan 2005) Üzerine, Uluslararası İlişkiler Dergisi 2(6), 151-155.

KAYFOR (2019). 23.02.2019 tarihinde http://kayfor.nny.edu.tr, adresinden erişildi.

Keskin, N. E. (2006). Türkiye'de kamu yönetimi disiplininin köken sorunu, Amme İdaresi Dergisi, 39(2), 1-28. 
Keyman, E. F., ve Ülkü, N. E. (2007). Türkiye üniversitelerinde uluslararası ilişkiler ders müfredatı. Uluslararası İlişkiler Dergisi, 4(13), 99-105.

Kiriş, H. M., ve Gül, H. (2017). Büyük veri analizi temelinde Türkiye'de siyaset bilimi ve kamu yönetimi (SBKY) ile kamu yönetimi (KY) bölümleri sıralaması ve değerlendirmesi. Süleyman Demirel Üniversitesi İktisadi ve İdari Bilimler Fakültesi Dergisi, 22(Özel Sayı), 2109-2131.

Ömürgönülşen, U. (2010). Türkiye'de lisans düzeyi kamu yönetimi öğretiminde yakın dönemde yaşanan gelişmeler: Mevcut durum, sorun alanları ve gelişme eğilimleri. Ankara Üniversitesi SBF Dergisi, 65(03), 123-161.

Özcan, G. (2007), Türkiye'de uluslararası ilişkiler alanında lisansüstü eğitiminin sorunları. Uluslararası İlişkiler Dergisi, 4(13), 107-112.

Polat, B. (2009). Катиоуu denetimi: Türkiye'de kamu yönetimi eğitiminin kamuoyu denetimine etkisi. Yayımlanmamış Yüksek Lisans Tezi, Gazi Üniversitesi Sosyal Bilimler Enstitüsü Siyaset Bilimi ve Kamu Yönetimi Bölümü, Ankara.

Seçkiner, E., ve Yıldız, M. (2013). Kamu yönetimi alanında düzenlenen bilimsel toplantıların gelişimi ve kurumsallaşması süreci: Kamu yönetimi forumu (KAYFOR) örneği, Nevşehir Hacı Bektaş Veli Üniversitesi SBE Dergisi, 2(1), 110-137.

Tepeciklioğlu, E. E. (2013). Türkiye'de uluslararası ilişkiler eğitimi: lisans ve lisansüstü ders programlarının karşılaştırmalı bir analizi, Ege Akademik Bakış Dergisi, 13(3), 303-316.

UIKK (2019). 04.05.2019 tarihinde https://www.uik.org.tr/36/tarihce, adresinden erişildi.

Yaman, A. (2009). Türk kamu yönetiminde yöneticilerin kamu yönetimi eğitimi açısından değerlendirilmesi. Yayımlanmamış Yüksek Lisans Tezi, Fırat Üniversitesi Sosyal Bilimler Enstitüsü Radyo Televizyon ve Sinema Anabilim Dalı, Elazığg.

Yalçınkaya, A., ve Efegil, E. (2009). Türkiye'de uluslararası ilişkiler eğitiminde ve araştırmalarında teorik ve kavramsal yaklaşım temelinde yabancılaşma sorunu. Gazi Akademik Bakış Dergisi, 3(5), 207-230.

YÖKATLAS (2019). 12.03.2019 tarihinde https://yokatlas.yok.gov.tr/tercihsihirbazi-t4-tablo.php? $\mathrm{p}=\mathrm{ea}$, adresinden erişildi. 


\title{
Kaynakça Bilgisi / Citation Information
}

\author{
Fedai-Mescioğlu, M. ve Fedai, R. (2019). İnterdisipliner eğitim politikası \\ üzerine bir değerlendirme: Uluslararası ilişkiler ve kamu yöne- \\ timi eğitimi OPUS-Uluslararası Toplum Araştırmaları Dergisi, \\ 13(19), 359-392. DOI: 10.26466/opus.584916
}

\section{Sonnot}

1 Yükseköğretim Kurumunun web sitesinde üniversitelerimiz kısmında meslek yüksekokulları da yer almaktadır. Ancak çalışmanın konusu bakımından bu üniversiteler çalışmaya dahil edilmemiştir. Derslerin isimleri ise olduğu gibi aktarılmıstır.

2 Yönetimi bilimleri fakültesinde işletme bölümü bulunmaktadır.

${ }^{3}$ Daha çok sağlık bilimleri üzerine yoğunlaşmıştır.

${ }^{4}$ SBKY Bölümü 1. Sını öğrencileri bulunmaktadır.

5 3. sınıf öğrencileri için seçmeli uluslararası ilişkiler, uluslararası hukuk dersi bulunmaktadır. 4. sınıf öğrencileri için zorunlu olarak Çağdaş Devlet Sistemleri dersi; seçmeli olarak ise Türk Dış Politikası, AB Entegrasyon Süreci ve Türkiye dersleri bulunmaktadır.

6 2. sınıfta Uluslararası iliş̧kiler dersi 4. sınıfta Türk Dış Politikası dersi zorunlu olarak verilmektedir. 3. sınıfta seçmeli olarak Uluslararası Hukuk, AB ve Türkiye, Uluslararası Örgütler dersi verilmektedir.

${ }^{7}$ Sağlık bilimleri alanında faaliyet göstermektedir.

${ }^{8}$ Bölüm aktif değildir.

${ }^{9}$ Ders programlarının 5 yarıyıl olarak hazırlanmasından bölümün yeni olduğu anlaşılmaktadır. Mevcut ders içeriklerinde Uluslararası ilişkilere ilişkin bir ders bulunmamaktadır.

${ }^{10}$ Bölüme ait ders içeriğine ulaşılamamıştır.

${ }^{11}$ AB ve Kamu Yönetimi, Devletler Özel Hukuku, Uluslararası Ilişkiler, Siyasi Tarih, Türk Dış Politikası dersleri seçmeli verilmektedir.

12 Şimdilik 2. sınıfa kadar olan öğrencilerin ders programı hazırlanmıştır. 1. sınıfta Siyaset bilimi, ikinci sınıfta ise Siyasi düşünceler tarihi dersleri bulunmaktadır. Yönetimim Bilimi ve Kamu Yönetimi dersleri ise 3. sınıf için seçmeli olarak okutulmaktadır. Idare hukuku, devlet ve bürokrasi dersleri seçmeli olarak 4. Sınıf dersleri arasında yer almıştır.

${ }^{13}$ 3. sınıfta Türk Dış Politikası dersi okutulmaktadır. Normal ve ikinci öğretim sınıfları mevcuttur.

${ }^{14}$ Fakülte ve bölümlere ulaşılamamıştır.

15 iiBF içinde Turizm işletmeciliği bölümü bulunmaktadır.

${ }^{16}$ Siyaset Bilimine Giriş, Kamu Yönetimine Girişi gibi dersler bulunmaktadır.

17 Bölüm Ingilizcedir. Zorunlu dersler arasında Uluslararası Illişkilere giriş, 19. ve 20. yy Diplomatik Tarih bulunurken, Uluslararası ilişkiler teorileri, uluslararası ilişkiler ve insan hakları, Avrupa bütünleşmesi, Türk Dış Politikası, Uluslararası Örgütler, Milliyetçilik Kuramları gibi seçmeli dersler de bulunmaktadır.

18 iiBF içinde Siyaset Bilimi isminde bir bölüm bulunmakta ancak bölümde eğitime başlanmamıştır.

${ }^{19}$ Söz konusu bölümler bulunmamaktadır.

${ }^{20}$ Aktif değildir.

${ }^{21}$ Gazi Üniversitesinden ayrılan iiBF bünyesinde SBKY bölümü bulunmaktadır. 1. sınıfta zorunlu Siyasi Tarih dersi bulunurken 3. sınıfta Uluslararası Hukuku dersi seçmeli 4. sınıfta Çağdaş Devlet Sistemleri dersi zorunludur. 
22 Üniversite istanbul Medipol üniversitesi gibi sağlık bilimleri üzerine kurulmuş ancak aktif duruma geçirilmemiştir.

${ }^{23}$ Ders içeriklerine ulaşılamamıștır.

${ }^{24}$ Siyaset Bilimi ve Kamu Yönetimi bölümü müfredatına bakıldığında siyaset bilimi ağırlıklı bir eğitim yürütüldüğü anlaşılmaktadır.

25 1. sınıfta zorunlu olarak Siyaset Bilimine Giriş dersi bulunmaktadır. 2. sınıfta ise seçmeli olarak Yönetim bilimi, idare Hukuku ve Karşılaştırmalı Siyaset dersi yer almaktadır. 3. sınıfta seçmeli olarak Current Political Issues in Turkey ve Political Regime in Turkey derslerinin yer alması Türkiye'de güncel politik sorunlara yer verilmesi bağlamında önem arz etmektedir. Her ne kadar bu tür derslerin seçmeli havuzunda yer alması öğrenci durumu sayısı ögretim üyesi durumu ile alakalı olarak değişiklik gösterse de programda yer verilmesi bölümün iç politikadan kopuk bir ders programı olmadığını kanıtlamaktadır.

${ }^{26}$ 1. sınıfta Siyasal Tarih dersi zorunlu iken seçmeli olarak Türk Dış Politikası dersi verilmektedir. 3. sınıfta Devletler Özel Hukuku Uluslararası Hukuk zorunlu; 4. sınıfta ise AB Hukuku dersi seçmeli olarak sunulmaktadır.

${ }^{27}$ Bölümün ders planında Siyaset bilimine giriş zorunlu iken seçmeli ders havuzunda ise Türk Siyaseti ve Uluslararası iliş̧kiler dersi bulunmaktadır. Kamu yönetimi ve iç politikaya yönelik bir ders bulunmamaktadir.

${ }^{28}$ Ingilizce eğitim verilen bölüm yeni açılması nedeniyle ilk iki sınıfa kadar olan ders programı mevcuttur. 2. sınıfta Dünya Siyasi Tarihi adında bir ders bulunmaktadır.

${ }^{29}$ Bölümün eğitim dili \%100 ingilizcedir. Bölümü ders programı incelendiğinde siyaset bilimi, karşılaştırmaları siyaset, Türk dış politikası, diplomasi gibi derslerin harmanlandığı görülmektedir. Seçmeli ders havuzunda ise iç politikaya yönelik sadece Türk Siyaseti isminde bir ders bulunmakta bu dersin ise Türk Siyasal Hayatı dersine benzer bir ders olduğu anlaşılmaktadır. Kamu Politikası, Afrika politikaları, Enerji politikaları, Küresel örgütler gibi dersler Siyaset Bilimi ve Uluslararası Illişkiler dersi için yeterli görülmektedir.

${ }^{30}$ 1. sınıfta siyaset bilimi, kamu yönetimi dersleri seçmeli ders havuzunda ise idare Hukuku dersleri bulunmaktadir.

${ }^{31}$ 2. sinıfta Uluslararası hukuk, 4. sınıfta ise uluslararası siyaset gibi dersler bulunmaktadır. Siyasi Tarih, Türk Dış Siyaseti, Türkiye AB ilişskileri gibi seçmeli dersler bulunmaktadır.

32 2. sinıfta uluslararası politika dersi zorunlu uluslararası insani sorunlar dersi ise seçmelidir. 3. sınıfta siyasi tarih ve Türk dış Politikası zorunlu uluslararası Güvenlik ve Terör, Ortadoğu da Toplum ve Siyaset, $A B$ Bütünleşmesi, uluslararası Örgütler, Uluslararası Hukuk dersi ise seçmelidir. 4. sınıfta Türkiye $A B$ ilişkileri zorunlu Milliyetçilik ve Azınlıklar, Türk Diplomasi Tarihi, Latin Amerika'da Toplum ve Siyaset ise seçmelidir.

${ }^{33}$ 1. sınıfta zorunlu olarak Siyaset bilimi ve yönetimi bilimi, 2 sınıfta ise Kamu Yönetimi dersi bulunmaktadir.

${ }^{34}$ 1. sınıfta zorunlu olarak Siyasi Tarih dersi bulunmaktadır. 2. sınıfta seçmeli olarak Uluslararası ilişkilere giriş dersi bulunmaktadır.

${ }^{35}$ Siyaset bilimi dışında kamu yönetimine ilişsin bir ders bulunmamaktadır. Güncel konulara ilişkin dersler bulunmaktadır. Örneğin Yükselen Çin: Çin'in Dış ve Ekonomi Politikalarında Güncel Meseleler gibi.

${ }^{36}$ Siyasi Tarih gibi zorunlu, $A B$ Hukuku ve Türkiye $A B$ ilişkileri gibi seçmeli dersler bulunmaktadır.

${ }^{37}$ Siyaset Bilimi, Küreselleşme ve Uluslararası iliş̧iler, AB gibi dersler bulunmaktadır.

${ }_{38}$ Üniversitede; Aydın iktisat Fakültesi, Söke İşletme Fakültesi ve Nazilli iiBF bulunmaktadır.

${ }^{39}$ Aydın iktisat Fakültesinde Uluslararası Iilişkiler bölümü ingilizce olarak verilmektedir. 1. Sınıfta siyaset bilimi 2. sınıfta ise Türk siyasal Yaşamı gibi dersler bulunsa da kamu yönetimine dair bir dersin bulunmadığı görülmektedir.

${ }^{40}$ Nazilli iiBF'de Uluslararası ilişskiler bölümünde ingilizce eğitim verilmektedir. Seçmeli ders havuzunda Yönetim bilimi, Idare hukuku gibi derslerin yanı sıra Yazııımın Temelleri, Mühendisliğe Giriş, Mühendislik Ekonomisi gibi dersler de sunulmaktadır. Ayrıca Uluslararası Iliş̧ilerin Türkçe eğitim veren bölümü de bulunmaktadir. 
${ }^{41}$ Kamu Yönetimi bölümü 2. sinıfta Siyasi Tarih I ve Siyasi Tarih II dersleri bulunmaktadır.

42 SBKY bölümünde uluslararası ilişkiler derslerine yer verilmemiştir. Insan Hakları ve Demokrasi Küreselleşme ve siyaset gibi dersler bulunsa da diğer üniversitelerde SBKY bölümlerinin aksine uluslararası ilişkilere giriş dersi bulunmamaktadır.

${ }^{43}$ Siyaset Bilimine Giriş ve Uluslararası Örgütler Türk Dış Politikası diplomasi gibi dersler bulunmakta iki disipline ilişkin oluşturulan sentez bölüm içeriği olarak sunulmaktadır. Kamu yönetimine ait özgün bir ders görülmemektedir.

${ }^{44}$ Bölüme ait ders içeriklerine ulaşılamamıştır.

${ }^{45}$ Karşılaştırmalı Yönetim Sistemleri isimli ders bulunmaktadır.

${ }^{46}$ 1. Ve 2. sınıfta Siyasi Tarih I ve II, Uluslararası Ilişkilere Giriș dersleri bulunmaktadır.

${ }^{47}$ 1. Sinıfta siyasi Tarih dersi 4. Sinıfta ise uluslararası hukuk dersi zorunlu olarak sunulmaktadır.

${ }^{48}$ Bölümün hem Türkçe hem de Ingilizce eğitim vermektedir. Uluslararası ilişkiler ve siyaset bilimi dersleri ağırlıkı olarak verilmektedir. Türk Siyasetinde Güncel Konular ve Karşılaştırmalı Politika dersi bulunmaktadır.

${ }^{49}$ Bölümlere ait ders içeriklerine ulaşılamamıştır.

${ }^{50}$ Uluslararası Illişkilere ilişkin bir ders bulunmamaktadır.

${ }^{51}$ Bölümde programın uzmanlık dersi olarak son sınıfta Gelişmekte Olan Ülkelerde Politika isimli bir ders bulunmaktadır. Oryantasyon dersi bulunmaktadır.

52 Hem Ingilizce hem de Türkçe eğitim verilmektedir. Politik Ekonomi, Karşılaştırmalı Siyasal Sistemler, Ortadoğu'da Siyaset ve Toplum, Gelişmekte Olan Ülkelerde Politika gibi dersler bulunmaktadır.

${ }^{53}$ Bölümün eğitim dili \%100 Ingilizcedir. Karşılaştırmalı Siyaset Politik Sosyoloji Türk Siyasal Hayatı gibi zorunlu Idare Hukuku ve Kent Sosyolojisi gibi seçmeli dersler bulunmaktadır.

${ }^{54}$ Sağlık alanında uzmanlaşmış bir üniversitedir.

55 3. sınıftan itibaren uluslararası ilişkiler, siyasi tarih dersleri okutulmaktadır. Türk Dış Politikası 21. Yüzyıl Siyasi Tarihi, Türk Dış Politikası dersleri bulunmaktadır. Küreselleşme ve Milliyetçilik gibi seçmeli dersler bulunmaktadır. 4. Sınıfta ise Devletler Hukuku Türkiye AB ilişskileri zorunlu dersler vardır.

${ }^{56} 1$. sınıf öğrencileri bulunmaktadır. Ayrıntıı ders programına ulaşılamamıştır.

57 iiBF bulunmamaktadır.

${ }^{58}$ 1. sinıfta Etik 2. sinıfta ise Idare Hukuku dersi zorunludur.

59 4. sınıfta zorunlu dersler arasında Türkiye'nin Dış Politikası ve Uluslararası Hukuk, Küreselleşme ve Uluslararası ilişskiler dersleri bulunmaktadır.

${ }^{60}$ Eğitim dili İngilizcedir. Türk Siyasetine Giriş, Siyaset Bilimi ve Araştırma Yöntemleri, Karşıllaştırmalı Siyaset Idare Hukuku, Karşılaştırmalı Devlet ve Bürokrasi, Çevre ve Siyaset, Devlet ve Kamusal Alan, Etik ve Siyaset gibi seçmeli dersler bulunmaktadır.

61 4. sınıfta Modern Devlet Sistemleri adlı zorunlu bir ders bulunmaktadır. Türkiye'nin Toplumsal Yapısı, idare Hukuku dersleri ise seçmeli olarak sunulmaktadır.

${ }^{62}$ Milliyetçilik Kuramları ve Milliyetçilik dersi seçmeli olarak sunulmaktadır.

${ }^{63}$ Türki Dış Politikası, Türkiye-AB ilişkileri dersleri seçmeli olarak sunulmaktadır.

${ }^{64}$ Siyaset bilimine giriș dersi bulunmaktadır.

${ }^{65}$ Bölüm, Uluslararası ilişskiler ve Siyaset Bilimi adıyla kurulmuştur. Siyaset Bilimi dersleri ağırıktadır. Kamu yönetimi idare hukuku yönetimi, bürokrasi örgüt gibi derslere yer verilmemektedir.

${ }^{66}$ Siyaset Bilimi ve Idare Hukuku gibi zorunlu dersler bulunmaktadır. Türk Siyasal Hayatı, Idari Yargı gibi seçmeli dersler bulunmaktadır.

${ }^{67}$ Uluslararası Ilişkiler, Uluslararası Sistemin Analizi, Uluslararası Hukuk, Uluslararası Güvenlik Stratejileri, Türk Dış Politikası, Uluslararası Örgütler, Uluslararası Terörizm ve Güvenlik gibi seçmeli dersler bulunmaktadır.

68 Üniversitede merkez kampüste SBF içinde Uluslararası Iliş̧kiler ve Siyaset Bilimi ve Kamu Yönetimi Bölümü bulunurken Biga IiBF'de Uluslararası Ilişkiler ve Kamu Yönetimi bölümleri bulunmaktadır. 
${ }^{69}$ Biga'da 2. sınıfta seçmeli olarak Kamu Yönetimi ve Türkiye'nin Toplumsal Yapısı dersi seçmeli olarak verilmektedir. 3. sınıfta İdare Hukuku zorunlu olarak verilmektedir. Merkezde ise bölüm yeni açılmış (ing) ve 1. Sınıf ögrencileri için program hazırlanmıştır.

70 2. sınıfta Siyasi Tarih I ve II dersleri, 4. sınıfta Uluslararası Hukuk, AB Kurumları ve Hukuku zorunlu uluslararası Örgütler I ve II ve Türk Dış Politikası ise seçmelidir.

71 2. sınıfta Siyasi Tarih I ve II, Avrupa Birliği I ve II dersleri zorunlu 4.sınıfta Uluslararası Hukuk dersi zorunlu, Uluslararası Örgütler I ve II, Dünya Siyaseti I ve II dersleri seçmelidir.

72 Türk Idare Tarihi, Siyaset Bilimi, Türk Siyaseti, Karşılaştırmalı Devlet ve Demokrasi, Çevre Politikaları, Türkiye-AB ilişkileri gibi dersler bulunmaktadır.

${ }^{73}$ Fakülte seçmeli dersleri kısmında Siyaset Bilimi ve Kamu Yönetimi dersleri seçmeli olarak sunulmaktadır.

${ }^{74}$ Fakülte seçmeli dersleri kısmında Uluslararası iliş̧iler dersleri seçmeli olarak sunulmaktadır.

${ }^{75}$ Siyaset Bilimi ve uluslararası ilişkilerde iki bölüm bulunmakta; Türkçe ve Ingilizce eğitim verilmektedir. Türk siyasal Yaşamında Güncel Konular, Idare hukuku, Göç Siyaseti, Karşılaştırmalı Siyasete giriş gibi dersler bulunmaktadır. 4. sınıfta ise Uluslararası Hukuk dersi seçmelidir.

76 1. sınıfta Siyasi Tarih dersi zorunlu üçüncü sınıfta ise Uluslararası Ilişkiler dersi 4. sınıfta ise Ulus ve Ulusçuluk dersi seçmelidir.

77 Akademik ve Sosyal Oryantasyon dersi zorunludur.

78 4. sınıfta Ortadoğu'da Siyaset ve Toplum dersi bulunmaktadır.

79 Işsletme Fakültesinde Uluslararası Illişkiler bölümü, iiBF'de ise Kamu Yönetimi bölümü bulunmaktadır.

80 Sosyal Sorumluluk Projesi adında zorunlu bir ders bulunması dikkat çekmektedir. 3. sınıfta verilen Türkiye'nin Siyasi Yapısı zorunlu iken Idare Hukuku dersi seçmelidir. İş Hayatında Kadınlar, Sinemada Uluslararası ilişkiler dersleri ise seçmeli olsa da oldukça dikkat çekmektedir.

81 2. sınıfta Siyasi Tarih dersi zorunlu iken Avrupa Birliği ve Türkiye dersi ise seçmelidir. 3. sınıfta Gelişmekte Olan Ülkelerde Politika dersi ise diğer özel üniversitelerde olduğu gibi müfredat eklenmiştir.

82 3. sınıfta Idare Hukuku dersi bulunmaktadır. Seçmeli olarak ise Türkiye'nin Toplumsal Yapısı, Yerel Yönetimler, Kamu Yönetimi gibi dersler yer almaktadır.

83 3. sınıfta zorunlu olarak Türk Siyasal Yaşamı I ve II dersi bulunmaktadır. 4.sınıfta seçmeli olarak idare Hukuku, Idari Yargı ve Türk Siyasal Yaşamında Güncel Sorunlar, Türkiye'de Anayasal Hareketler isimli dersler bulunmaktadır. Üniversiteye özgü olarak Topluma Hizmet Grupları ve ayrıca Transition into Univesity Life isimli seçmeli dersleri bulunmaktadır.

${ }^{84}$ 2. sınıfta Idare hukuku 4. sınıfta ise Kamu Yönetimi dersleri zorunludur. Sanat ve Uluslararası Politika adında seçmeli ders bulunmaktadır.

85 4. sınıfta zorunlu olarak $A B$ ve Türkiye dersi, seçmeli olarak Türk Dış Politikası, Milliyetçilik, Küreselleşme ve Azınlıklar deri bulunmaktadır.

${ }^{86}$ SBKY bölümündeki seçmeli derslerin yanında Toplumsal Sorumluluk ve Vergi Bilinci, Psikolojik Başarı Teknikleri dersleri bulunmaktadır. 2. sınıfta Türk Siyasal Hayatı, Siyasi Düşünceler Tarihi zorunlu iken, 4 sınıfta Strategic Management dersi seçmeli olarak sunulmuştur.

${ }^{87}$ Sinema Kültürü, Web Tasarımı gibi seçmeli dersler bulunmaktadır. 3. sınıfta seçmeli olarak uluslararası ilişkiler, Türk Dış Politikası gibi dersler bulunmaktadır. 4. sınıfta seçeli olarak Ortadoğu, Uluslararası Hukuk, Diplomasi, $A B$ ve Türkiye dersleri vardır.

${ }^{88}$ Yeni kurulan üniversitede Siyaset Bilimi ve Uluslararası Ilişkiler bölümünün Türkçe ve Ingilizce olmak üzere iki bölüm halinde eğitim vereceği belirtilmektedir. Ancak bölümler halen aktif değildir.

${ }^{89}$ 4. sınıfta zorunlu olarak AB'nin Siyasi ve Hukuki Yapısı dersi bulunmaktadır.

${ }^{90}$ Siyaset Bilimi, Siyasi Düşünceler Tarihi, Türk Siyasal Yaşamı gibi dersler bulunmaktadır.

${ }^{91}$ Islahiye iiBF'de Kamu Yönetimi bölümünde 3. ve 4. sınıfta Uluslararası Illişkilerde Güncel Konular, Ulusal ve Uluslararası Güvenlik Stratejileri, Türkiye AB iliş̧kileri, Türk Dış Politikası, Etnisite ve Milliyetçilik dersi zorunlu iken Siyasi tarih dersi seçmelidir. 
92 2. sınıfta seçmeli olarak Uluslararası ilişkiler ve Uluslararası Hukuk dersi bulunmaktadır. 3. sınıfta seçmeli olarak Terörizm ve Siyaset dersi bulunurken 4. sınıfta zorunlu Türk Dış Politikası dersi bulunmaktadir.

93 1. sınıfta Siyaset Bilimi ve Çağdaş Siyasi Düşünceler Tarihi Türk Siyasal Hayatı I ve II ise 2. sınıfta seçmeli olarak sunulmaktadır. 4 sınıfta seçmeli olarak Urban Studies dersi bulunmaktadır.

94 1. sınıfta zorunlu olarak Siyasi Tarih dersi 2. Sınıfta ise Uluslararası İlişkiler dersi bulunurken 2. sınıfta Enerji Güvenliği ve Politikaları Kamu diplomasisi, Silahlı Çatışma Hukuku seçmeli olarak verilmektedir. 3. sınıfta seçmeli olarak Jeopolitik ve Türkiye, Actual Problems in Turkish Foreign, States and Societies in the Middle East dersleri bulunmaktadır. 4. sınıfta zorunlu olarak Ulusal ve Uluslararası Güvenlik Türk Dış Politikası dersleri zorunlu iken ABD Dış Politikasının Küresel Etkileri, Milliyetçilik, Küreselleşme ve Azınlıklar dersleri seçmelidir.

95 Üniversitenin Bologna ders bilgi paketinde 4 yarıııla ait veriler bulunmaktadır.

${ }^{96}$ 2. sınıfta Uluslararası ilişkiler 20. yy. Siyasi Tarih dersleri 3 ve 4. sınıfta ise Türk Dış Politikası, AB'nin Dış Politika Analizi, Uluslararası Iletişim ve Siyaset, Türkiye-AB ilişkileri dersleri zorunlu olarak verilmektedir.

97 Bölüm eğitim dili ingilizcedir. Türk Siyasi Yapısı ve Siyaseti gibi dersler az sayıda olmakla birlikte kamu yönetimine ilişkin başka bir ders bulunmamaktadır.

98 1. sınıfta Dünya Tarihi I ve II dersleri, 4. Sınıfta seçmeli olarak ise Güvenlik Çalışmaları, AB Çalışmaları, Ortadoğuda Toplum ve Siyaset gibi dersler bulunmaktadır.

99 1. sınıfta kamu yönetimi 2. sınıfta yerel yönetimler 4. Sınıfta ise Kentleşme ve Çevre Sorunları dersleri zorunludur.

100 Siyaset Bilimine Giriş, Uluslararası ilişkilere Giriş gibi bölümün adını yansıta ortak dersler bulunmaktadır.

101 2. sınıfta Siyasi Tarih dersi zorunlu olmakla birlikte Uluslararası Ilişkiler, Uluslararası Politikada Ortadoğu, Uluslararası Hukuk, Türk Dış Politikası, AB ve Türkiye dersleri seçmeli ders havuzunda yer almaktadır.

102 Üniversiteye özgü olarak Toplumsal Duyarlılık Projeleri I ve II adında dersler bulunmaktadır. 2. sınıfta Karşılaştırmalı Politika I ve II, 3. sınıfta Türk Siyasal Hayatı I ve II, 4. sınıfta ise Türkiye'nin Yönetim Yapısı adlı zorunlu dersler bulunmaktadır.

103 2. sınıfta $A B$ Hukuku dersi 3. sınıfta ise Uluslararası Ilişkiler 4. sınıfta Siyasal Tarih seçmeli olarak sunulmaktadır. Bölüme özgü olarak Denetimli Serbestlik, Çevresel Etki Değerlendirme dersi (içeriğine ulaşılamasa da) yine seçmeli dersler arasındadır.

104 2. sınıfta Siyasi Tarih I ve II dersleri zorunlu 4. sınıfta ise Uluslararası Politika, Uluslararası Hukuk dersleri zorunludur.

105 1. sınıfta Dijital Okuryazarlık adında bir ders bulunmaktadır. Temel Bilgi Teknolojileri dersi ayrı bir ders olarak sunulmuştur. 4. sınıfta AB Siyasal Yapısı, Uluslararası ilişkiler dersleri bulunmaktadır.

106 Siyaset Bilimine Giriş, Karşılaştırmalı Siyaset, Siyaset Kuramı, Siyaset Sosyolojisi gibi dersler ağırlıklı iken Uluslararası Ekoloji ve Çevre Politikaları, Türk Siyasi Düşüncesi, Kamu Siyasası gibi dersler de bulunmaktadır.

107 Ege Üniversitesinde olduğu gibi Introduction to University Life dersi bulunmaktadır. 2. sınıfta ise History of Modern Turkey I ve II dersleri 4. Sinıfta ise Turkish Politics dersi zorunludur. Administrative Law, Current Issues in Turkish Politics dersleri ise seçmelidir.

108 Üniversiteye özgü olarak 2. sınıfta Üniversite Etkinlik Programı I ve II adlı dersler bulunmaktadır. Kentsel Sürdürülebilirlikte Güncel Sorunlar, Insan Kaynakları Yönetiminde Güncel Uygulamalar, Kamu Sektörü Yönetişimi, Idare Hukuku gibi tüm bölümlerin derslerinin yer aldığı seçmeli ders havuzuna ilave olarak sınırlı seçmeli dersler (AB’nde Kamu Politikası, Küresel Yönetişim, Çevre, Iklim Değişikliği ve Sürdürülebilir Kalkınma gibi) de yer almaktadır.

109 Üniversiteye özgü olarak Üniversite Hayatına Giriş, Üniversite Etkinlik Programı I ve II dersleri bulunmaktadır. Seçmeli dersler ise Uluslararası Ilişkiler bölümünde olduğu gibi geniş (Diplomasi Tarihi, uluslararası Hukuk, Uluslararası Örgütler gibi) ve sınırlı olmak üzere (Siyaset Bilimi ağırlıklı) iki kısımdan oluşmaktadır. 
110 2. sınıfta Türkiye'nin Toplumsal Yapısı dersi, 3. sınıfta ise Türk Siyasal Hayatı I ve II, Türkiye'de Güncel Siyasal Sorunlar dersleri, 4. sınıfta ise idare Hukuku I ve II dersleri zorunlu olarak sunulmaktadır. Küreselleşme ve Yerelleşme, Yönetim Bilimi dersleri ise seçmelidir.

111 Çevresel Etki Değerlendirmesi dersi seçmeli olarak sunulmaktadır. 2. sınıfta Siyasi Tarih, 3. sınıfta Uluslararası Iliş̧kiler, Terörizm ve Siyaset 4. sınıfta Türk Dış Politikası dersi zorunludur.

112 iki bölüm olarak hem Ingilizce hem de Türkçe eğitim verilmektedir. 1. sınıfta Yönetim Bilimi dersi 3. sınıfta ise Türk Siyasal Hayatı dersi verilmektedir.

113 2. sınıfta Uluslararası iliş̧kilere Giriş, Türk Dış Politikası dersleri seçmeli olarak ise Uluslararası Örgütler, Ortadoğu ve Siyaset dersleri bulunmaktadır.

${ }^{114}$ Siyaset Bilimine Giriş, Uluslararası Ilişkilere Giriş gibi dersler bulunmaktadır.

115 1. sınıfta Siyaset Bilimine Giriş, 2.sınıfta Türk Siyasal Hayatı, Siyasal Düşünceler Tarihi I ve II dersleri bulunmaktadır.

${ }^{116}$ Bölüm İşletme ve Yönetim Bilimleri Fakültesinde bulunmaktadır. 1. sınıfta Siyaset Bilimine Giriş, Kamu Yönetimine Giriş, Uluslararası Illişkilere Giriş dersleri bulunmaktadır. 2. sınıfta Kamu Yönetiminde Çağdaş Yönetim Anlayışları, 3. sınıfta Türkiye'de Siyasal Yapı ve Hayat I ve II, 4. Sınıfta Karşılaştırmalı Kamu Yönetimi, Türk Siyasetinde Güncel Konular dersleri bulunmaktadır.

117 2. sınıfta Türk Siyasal Rejimi dersi zorunlu iken Kamu Politikaları, Kentleşme Politikası, Yerel Yönetimlerde Yeni Eğilimler, Yerelden Küresele Çevre Politikaları, dersleri ise seçmelidir.

118 2. sınıfta 20.yy Siyasi Tarihi dersi, 4. sınıfta Türk Dış Politikası zorunlu iken 3. sınıfta seçmeli olarak Uluslararası iliş̧kiler, Orta doğuda Siyasal Sorunlar dersleri bulunmaktadır.

119 1. sınıfta Kamu Yönetimi dersi bulunmaktadır.

${ }^{120}$ SBKY bölümünde Sürdürülebilirliğe Giriş dersi bulunmaktadır.

121 insan ve Toplum Bilimleri Fakültesi bünyesinde kurulmuştur. 2. sınıfta Uluslararası Hukuk ve Uluslararası iliş̧kiler dersleri zorunludur.

122 Introduction to Turkish Politics dersi bulunmaktadır.

123 1. sınıfta Siyaset Bilimine giriş, 2. sınıfta Türk Siyasal Hayatı dersleri zorunlu iken

124 SBKY bölümü (üç bölüm) \%100 ingilizce, \%30 ingilizce ve Türkçe eğitim vermektedir. 1. sınıfta Uluslararası iliş̧kilere Giriş 2. sınıfta ise Siyasi Tarih dersi bulunmaktadır. 3. sınıfta seçmeli olarak uluslararası Hukuk ve Kuruluşlar, Türkiye-AB ilişkileri dersleri bulunmaktadır.

125 3. sınıfta Türkiye Siyaseti dersi zorunlu iken Türk Idare Tarihi seçmelidir.

${ }^{126}$ 2. sınıfta Türkiye Siyasi Tarih dersi 4. sınıfta seçmeli olarak Uluslararası ilişkiler dersi bulunmaktadır.

127 Bölümde hem Türkçe hem de Ingilizce eğitim vermektedir. 1. sınıfta Siyaset Bilimine Giriş, 3. sınıfta Türkiye'de Modernleşme, 4. sınıfta Türkiye Politikasında Güncel Sorunlar dersleri bulunmaktadır.

128 1. sınıfta Siyaset Bilimine Giriş I ve II, 2. sınıfta Idare Hukuku dersi zorunlu iken yine 2. sınıfta Çağdaş Yönetim Teknikleri 3. sınıfta ise Bilgi Toplumu ve E-Devlet dersi ise seçmelidir.

${ }^{129}$ Çatışma Yönetimi ve Müzakere Yönetimi, Ortadoğu ve Siyaset gibi dersler seçmeli olarak sunulmuştur.

130 Türkiye'de Sivil Toplum ve Demokrasi, Modern Siyaset Düşüncesi, Din ve Siyaset, Çevre Politikaları gibi dersler bulunmaktadır.

131 Üniversitede Türkçe ve Ingilizce olmak üzere iki bölümde ders verilmektedir. Siyaset Bilimi, Siyaset Düşüncesinin Antik Temelleri, Anayasa Siyaseti, Çağdaş Uluslararası Siyaset dersleri gibi siyaset bilimi ağırlıklı dersler zorunlu olarak okutulurken fakülte seçmeli ders havuzunda diğer bölümlerden ders seçme olanağı verilmiştir.

132 Siyaset Bilimine Giriş, Siyasi Tarih, Uluslararası Ilişkilere Giriş, Idare Hukuku, Uluslararası Güvenlik, Savaş Hukuku gibi her iki disiplinden de dersler bulunmaktadır.

133 1. sınıfta Siyasi Tarih dersi zorunlu iken 2. sınıfta Türkiye ve AB ilişkileri dersi seçmelidir. 4. sınıfta AB Hukuku dersi zorunludur.

${ }^{134}$ Siyaset Bilimi, Uluslararası Ilişkilere Giriş, Siyasi Tarih, Türk Dış Politikasının Temel Konuları gibi zorunlu dersler bulunmaktadır. Türk Siyasi Düşüncesinin Evrimi, Türk Siyasi Tarihi gibi seçmeli dersler de müfredata konulmuştur. 
${ }^{135}$ Eğitim dili Ingilizcedir. Introduction to International Relations, International Organizations, Turkish Politics, Turkish Foreign Politics gibi siyaset biliminden ziyade uluslararası ilişkiler disiplini ağırıklı dersler bulunmaktadır.

${ }^{136}$ Eğitim dili Ingilizce olan bölümde Turkish Politics 1923-1980, Contemporary Turkish Politics, dersleri zorunlu iken Administrative Law, European Union and Turkey Relations dersleri ise seçmelidir.

137 1. sınıfta Siyasi Tarih dersi zorunlu iken Uluslararası Örgütler alan dışı seçmeli ders olarak sunulmaktadir.

138 2018-2019 yılı eğitim öğretim döneminde öğrenci alımına başlanmıștır.

139 1. Sınıfta Dünya Siyasi Tarihi dersi, 2. sınıfta Türkiye Siyasi Tarihi, 3. sınıfta Uluslararası Ilişskiler Tarihi, Uluslararası Örgütler dersleri zorunlu iken 4. sınıfta Avrupa Birliği ve Türkiye ilişkileri, Uluslar ve Milliyetçilik dersleri ise seçmelidir.

${ }^{140}$ 2.sınıfta Türk Siyasi Hayatı dersi, 3. Sınıfta ise Türk Siyasetinde Güncel Konular dersi bulunmaktadır.

${ }^{141}$ Bölüm aktif değildir.

${ }^{142}$ Bölümün ders içeriklerine ulaşılamamıştır.

${ }_{143}$ 2. sınıfta Siyaset Bilimine Giriş dersi 3. sınıfta ise Türk Siyasal Yaşamı dersi bulunmaktadır.

144 Uluslararası ilişkilere ait bir ders bulunmamaktadır.

145 Siyaset Bilimine Giriş I ve II, Uluslararası Illişkilere Giriş I ve II, Uluslararası Hukuk, Türk Dış Politikası gibi dersler bulunurken 4. sınıfta seçmeli olarak Idare Hukuku dersi bulunmaktadır.

146 Uluslararası Hukuk, Dünya Siyasi Tarihi I ve II, AB Siyasal Sistemi ve Hukuku dersi seçmeli olarak sunulmaktadir.

147 4. sınıfta Uluslararası Iliş̧kiler, Türk Dış Politikası, AB Siyasal Yapısı dersleri zorunludur.

148 1. sınıfta Yönetim Bilimi, 2. sınıfta Türk Kamu Yönetimi ve Idare Hukuku dersleri zorunludur.

149 Uluslararası Ilişskiler, Siyaset Bilimi, Uluslararası Hukuk gibi dersler bulunmaktadır. Afet Yönetimi, idari Yargı gibi seçmeli dersler bulunmaktadır.

${ }^{150}$ Dünya Tarihi dersi zorunlu, AB ve Türkiye ilişkileri dersi ise seçmelidir. Kamusal Akıl Stüdyosu adında iki dönem halinde verilen bir ders de yer almaktadır.

${ }^{151}$ 2. sınıfta Siyasi Tarih I ve II dersleri zorunlu iken 3. sınıfta Uluslararası Ilişkiler, Türkiye AB ilişkileri dersleri seçmelidir.

152 2. sınıfta Türk Siyasal Hayatı I ve II dersleri bulunmaktadır.

${ }^{153}$ Ders bilgi paketinde Uluslararası ilişkilere yönelik bir ders bulunamamaktadır.

${ }^{154} 2$ 2. sınıfta Idare Hukuku dersi zorunlu olarak verilirken, Türkiye'nin Toplumsal Yapısı ve Türk Idare Tarihi dersleri seçmeli olarak sunulmaktadır.

155 3. sınıfta seçmeli olarak Kamu Diplomasisi, AB ve Türkiye adında dersler bulunmaktadır. 4. sınıfta ise Bürokrasi ve Siyaset isimli seçmeli bir ders bulunmaktadır.

${ }^{156}$ 2. sınıfta zorunlu dersler arasında Türk Siyasal Hayatı dersi 3. sınıfta seçmeli ise olarak Yönetim Bilimlerine Giriş dersi bulunmaktadır. 4. sınıfta zorunlu olarak idare Hukuku bulunmaktadır.

157 1. sınıfta zorunlu olarak Siyasal Tarih dersi bulunmaktadır. 3. sınıfta seçmeli olarak Avrupa Birliği ve Türkiye ve Uluslararası Hukuk ve Türk Dış Politikası gibi dersler seçmeli olarak sunulmaktadır.

158 1. sınıfta Siyaset Bilimi dersi bulunurken 2. sınıfta zorunlu olarak Türk Siyasi Hayatı (1945-1990) dersi seçmeli olarak ise Yönetim Bilimine Giriş dersi bulunmaktadır.

159 1. sınıfta Siyasi Tarih dersi 3. sınıfta ise AB Kurumları ve Politikaları dersi zorunludur. 4. Sinıfta Current Issue in the EU dersi ise seçmelidir.

160 1. sınıfta Siyaset Bilimine Giriş dersi bulunurken 2. Sınıfta seçmeli olarak Kamu Yönetimine Giriş ve Türkiye'nin Toplumsal Yapısı dersleri bulunmaktadır. 4. Sınıfta zorunlu olarak Karşılaştırmalı Siyaset dersi vardir.

161 2. sınıfta seçmeli olarak Uluslararası Örgütler ve Uluslararası Ilişkiler dersleri bulunmaktadır. 3. sınıfta zorunlu olarak Siyasi Tarih dersi seçmeli olarak ise Türkiye AB Iliş̧kileri, Uluslararası Hukuk dersleri sunulmaktadır. 
162 1. sınıfta zorunlu olarak Siyaset Bilimi dersi 2.sSınıfta seçmeli olarak idare Hukuku dersi bulunmaktadır. Fakültenin ikinci bir bölüm olarak Uluslararası ilişskiler \%30 ingilizce olarak eğitim veren başka bir bölümü de bulunmaktadır.

163 2. sınıfta Siyasi Tarih 3. sınıfta ise Uluslararası Hukuk 4. Sınıfta Devletler Özel Hukuku dersleri seçmeli olarak sunulmaktadır.

164 2. sınıfta seçmeli olarak Uluslararası ilişkiler ve Uluslararası Hukuk dersleri bulunmaktadır. 3. sınıfta seçmeli olarak Ortadoğu Tarihi, Devletler Özel Hukuku Terörizm ve Siyaset 4. sınıfta zorunu olarak Türk Dış Politikası seçmeli olarak ise AB Hukuku dersi bulunmaktadır.

165 1. sınıfta Siyaset Bilimi dersi 2. sınıfta Türk Siyasal Hayatı dersi bulunmaktadır. 3. sınıfta seçmeli olarak idare Hukuku dersi bulunmaktadır.

166 2. sınıfta seçmeli olarak Uluslararası ilişkiler dersi bulunmaktadır. 4. sınıfta ise seçmeli olarak Avrupa Birliği'ne Yönetsel Uyum dersi bulunmaktadır.

${ }^{167}$ Karşılaştırmalı Siyasete Giriş, Politika Analizine Giriş Toplumsal Cinsiyet ve Siyaset derslerinin yanı sıra Türkiye Politikasındaki Çağdaş Konular, Türkiye Siyasetindeki Konular gibi dersler bulunmaktadır.

168 2. sınıfta Siyasi Tarih ve 3. sınıfta ise Uluslararası ilişkiler dersleri zorunlu olarak verilmektedir. 4. sınıfta seçmeli olarak Türkiye-Ortadoğu Ilişskileri, Türkiye AB ilişkileri dersleri sunulmaktadır.

169 2. sınıfta Yönetimi Bilimi, 3. sınıfta ise Türk Siyasal Hayatı ve Türkiye'nin Idari Yapısı dersleri zorunlu iken Idare Hukuku ve Bürokrasi dersleri ise seçmelidir. 4. sınıfta Yönetim Sistemleri zorunlu iken Karar Alma Kuramları dersi seçmelidir.

170 2. sınıfta Kamu Yönetimine Giriş, Karşılaştırmalı Kamu Yönetimi dersleri zorunlu olarak verilmektedir.

171 3. sınıfta Siyasi Tarih, Avrupa Birliği ve Türkiye, Uluslararası Politika gibi seçmeli dersler bulunmaktadır.

172 4. sınıfta Global Governance adlı zorunlu bir ders bulunmaktadır. Seçmeli ders havuzunda ise Turkish Public Administration, Immigration Politics and Policy International Publi Policy, Politics and Ethics dersleri sunulmaktadır.

173 3. sınıfta Türkiye'de Siyasal Hayatın Dönüşümü I ve II, Yerel Yönetimler ve Yerel Siyaset, Siyasal Ekoloji dersleri bulunmaktadır. 4. sınıfta Avrupa Birliği Bölgesel Yönetim Politikaları, Küresel Çevre Siyaseti, Çevre Politikaları gibi dersler bulunmaktadır.

174 1. sınıfta Kamu Yönetimi dersi, 2. sınıfta ise Idare Hukuku ve Idari Yargı, Türkiye'de Siyasal Hayat dersleri verilmektedir.

175 Bölüm eğitim dili Ingilizcedir. 3. sınıfta Turkish Politics Comparative Politics I ve II dersleri verilmektedir. 4. sınıfta seçmeli olarak International Migration dersleri sunulmaktadır. Üniversite seçmeli ders havuzunda ise Public Administration in Turkey, Les Administrations Locales, Les Problemes de Environment dersleri sunulmaktadır.

176 Fakültede eğitim dili olarak Fransızca ve Türkçe eğitim verilen bölümler bulunmaktadır. 2. sınıfta International Relations dersi zorunludur. Seçmeli ders havuzunda ise Public Diplomacy, Nations and Nationalism, International Organizations European Union and Turkey, gibi dersler bulunmaktadır.

177 Eğitim dili Ingilizcedir. 1. sınıfta Introduction to Business (Decision-making) adlı bir ders bulunmaktadır.

178 2. sınıfta Türk Siyasal hayatı 4. sınıfta ise Idare Hukuku dersleri zorunludur.

179 4. sınıfta Uluslararası Politika, Uluslararası Ilişkiler, Türk Dış Politikası dersleri seçmeli olarak sunulmaktadır.

180 1. sınıfta Siyasi Tarih dersi zorunlu 3. sınıfta Uluslararası Ilişkiler, Insan Hakları dersleri seçmelidir. 4. sınıfta Avrupa Birliği Türkiye Ilişkileri, Uluslararası Hukuk, Türk Dış Politikası dersleri seçmelidir.

${ }^{181}$ 2. sınıfta Türk Siyasi Tarihi dersi zorunlu iken 3. sınıfta Idare Hukuk dersi seçmelidir. 4. sınıfta Siyaset ve Etik dersi seçmelidir.

182 2. sınıfta Uluslararası ilişkiler, Uluslararası Hukuk dersleri, 3. sınıfta Türk Dış Politikası dersi zorunludur. 3. sınıfta Milliyetçilik, Küreselleşme ve Azınlıklar dersi 4. sınıfta ise Uluslararası Güvenlik Stratejileri, Uluslararası Örgütler, ABD Dış Politikası, Ortadoğu'da Siyaset dersleri seçmelidir. 
183 1. sınıfta Siyasi Tarih dersi 3. sınıfta ise Avrupa Birliği ve Türkiye dersi zorunludur. 3. sınıfta Uluslararası Iilişkiler ve Türk Dış Politikası dersleri seçmelidir. 4. Sınıfta seçmeli olarak Türkiye Ortadoğu ilişkileri, Türkiye Kafkasya ilişkileri dersleri bulunmaktadır.

184 Siyasal Bilgiler Fakültesinde bünyesinde kurulan bölümde 2. sınıfta zorunlu olarak Yönetim Bilimi dersi bulunmaktadır. 3.sınıfta seçmeli olarak Çevre Politikası adında bir ders bulunmaktadır.

185 3. sinıfta Siyasi Tarih dersi zorunludur.

${ }^{186}$ 2. sınıfta zorunlu olarak Idare Hukuku dersi vardır. 4. sınıfta ise Karşılaştırmalı Siyasal Sistemler dersi zorunludur.

187 2. sınıfta uluslararası ilişskiler ve Politika deri zorunludur. 4. sınıfta seçmeli olarak Avrupa Birliği'nin Siyasi ve Hukuki Yapısı ve Uluslararası Hukuk dersleri seçmelidir.

188 3. sınıfta seçmeli olarak Avrupa Birliği Türkiye ilişkileri dersi bulunurken 4. Sınıfta ise seçmeli olarak Uluslararası Hukuk ve Devletler Özel Hukuku dersleri bulunmaktadır.

189 3. sınıfta zorunlu olarak Türk Siyasi Hayatı dersi seçmeli olarak ise Türk Idare Hukuku, Türk Siyasal Düşüncesi dersleri bulunmaktadır. 4. Sınıfta ise Türk Idare Tarihi dersi seçmelidir.

190 2. sınıfta Karşılaştırmalı Siyasal Sistemler isimli zorunlu bir ders bulunmaktadır. 3. sınıfta seçmeli olarak Türk Siyasal Hayatı ve Siyaset Sosyolojisi dersleri bulunmaktadır. 4. Sınıfta kentleşme Politikaları adında seçmeli bir ders vardır. Diğer üniversitelerden farklı olarak bölümün 4. sınıfında Endüstri 4.0 ve Dijital Dönüşüm, Bir Firmada Kadrolu Çalışmak gibi dersler bulunmaktadır.

191 2. sınıfta Uluslararası Ilişkiler Tarihi, Avrupa Birliği ve Türkiye, Uluslararası Hukuk dersleri 3. sınıfta ise Türk Dış Politikası dersi seçmelidir.

192 2. sınıfta seçmeli olarak $A B$ ve Türkiye dersi bulunmaktadır. 4. Sınıfta zorunlu olarak Uluslararası Ilişkiler dersi seçmeli olarak ise Türk Dış Politikası ve Siyaseti dersi vardır. Üniversiteye özgü olarak ise Sağlığın Korunması ve Geliştirilmesi ve Kamuda Kariyer Planlaması isimli dersler bulunmaktadır.

1932016 yılında kurulan bölüme ait ders içeriklerinde Siyaset Bilimi ve Kamu Yönetimi bölümünün dersleri yer almaktadır. Uluslararası ilişskiler derslerinin seçmeli olarak verildiği görülmektedir. Dolayısıyla ders içeriklerinin hatalı olarak girildiği ifade edilebilir.

194 3. sınıfta seçmeli olarak Ortadoğu Siyaseti, Uluslararası Örgütler, TC-AB iliş̧kileri 4. sınıfta ise seçmeli olarak Uluslararası Ilişkiler Milliyetçilik Kuramları, Türk Dış Politikası Siyasi Tarih dersleri bulunmaktadır.

195 3. sınıfta zorunlu olarak Siyasi Tarih I ve II dersleri bulunmaktadır. 4. sınıfta zorunlu olarak Uluslararası Politika ve Türk Dış Politikası dersleri bulunmaktadır. Ortadoğu'da Ekonomi Toplum Siyaset dersi ise seçmelidir.

${ }^{196}$ Bölüm 2018-2019 eğitim ve öğretim yılında öğrenci alımına başlamıştır.

197 3. sınıfta zorunlu olarak Siyasi Tarih I ve II dersleri bulunmaktadır. Uluslararası Ilişkiler, AB ve Türkiye dersleri ise seçmelidir. 4. sınıfta verilen Türk Dış Politikası, Ortadoğu'da Toplum ve Siyaset dersleri seçmelidir.

198 1. sınıfta Siyaset Bilimine Giriş, Karşılaştırmalı Siyaset dersleri bulunmaktadır. Alan içi seçmeli dersler arasında ise Kentsel Politikalar: Kentlerin Sosyolojisi dersi yer almaktadır.

199 4. sınıfta Uluslararası Iilişkiler ve Dış Politika, Türk Dış Politikası dersleri zorunlu iken AB Yapısı ve Politikaları, 20. Yüzyıl Siyasi Tarihi dersleri seçmelidir.

200 2. sınıfta Türkiye'de Siyasal Hayat ve Karşılaştırmalı Siyaset dersleri seçmeli olarak sunulmaktadır.

201 2. sınıfta uluslararası ilişkiler dersi seçmeli olarak verilmektedir. 4. sınıfta Türkiye Dış Politikası ve Uluslararası Hukuk dersleri seçmeli iken Siyasi Tarih dersi ise zorunludur. 3. sınıfta Idare Hukuku dersi seçmelidir.

${ }^{202}$ Küresel Idare adındaki ders içerik itibariyle Uluslararası Örgütler dersine benzemektedir. Dünya Politikaları adı ders içeriğinde uluslararası krizlerin iç politikaya etkileri ele alındığı ifade edilmektedir.

203 2. sınıfta Türk Siyasi Hayatı ve Idare Hukuku dersleri zorunludur. 3. sınıfta Kentleşme ve Çevre SorunIarı, Kamu Yönetimi, Yerel Yönetimler dersleri ise seçmelidir. 4. sınıfta fakülte dersleri seçmeli olarak sunulmakta burada ise E-Devlet Uygulamaları dersi göze çarpmaktadır.

204 2. sınıfta Uluslararası Ilişkiler ve Türk Dış Politikası dersleri zorunludur. 3. ve 4. sınıfta Uluslararası Hukuk, Siyasi Tarih, Uluslararası Örgütler, Terörizm, Uluslararası Güncel Sorunlar dersleri seçmelidir. 
205 2. sınıfta Idare Hukuku dersi zorunlu olarak verilmektedir. Siyaset Sosyolojisi ve Psikolojisi dersi zorunlu iken Yönetim Psikolojisi dersi seçmeli olarak sunulmaktadır. 3. sınıfta Türk Siyasi Hayatı zorunludur. 4. sınıfta zorunlu olarak Türkiye AB ilişskileri dersi verilmektedir.

${ }^{206}$ 2. sınıfta Siyasi Tarih dersi zorunludur.

207 3. sınıfta Siyasi Tarih dersi seçmelidir. 4. sınıfta Uluslararası Ilişkiler ve Türk Dış Politikası dersleri zorunlu olarak verilmektedir.

208 3. sınıfta Siyasi Tarih ve Uluslararası İlişkiler dersleri zorunludur. Seçmeli ders bilgilerine yer verilmemiştir.

209 2. sınıfta Siyasal Düşünceler Tarihi I ve II dersleri zorunlu iken Kamu Yönetimi dersi seçmelidir. 3. Sınıfta Yönetim Hukuku dersi zorunlu Idari Yargılama Hukuku dersi ise seçmelidir. 4. Sınıfta Türkiye Avrupa Birliği iliş̧kileri dersi seçmelidir.

210 2. sınıfta seçmeli olarak Siyasi Tarih ve Türk Dış Politikası Analizi dersleri verilmektedir. 3. sınıfta seçmeli olarak Uluslararası Politika dersi bulunmaktadır.

211 2. sınıfta seçmeli olarak Uluslararası Hukuk dersi bulunmaktadır. 4. sınıfta seçmeli olarak AB Türkiye ilişkileri ve Uluslararası ilişkiler dersleri bulunmaktadır.

212 Global Çevre Sorunları, Global Siyaset, Modern Türkiye'nin Oluşumu, Türkiye Avrupa Birliği Bütünleşmesi, Uluslararası Politikada Etik, Devletler Umumi Hukuku gibi dersler bulunmaktadır.

213 1. sınıfta Siyaset Bilimine Giriş I ve II dersleri zorunludur. 2. sınıfta seçmeli olarak Siyaset Sosyolojisi ve Türk Siyasal Hayatı dersleri 3. sınıfta seçmeli olarak Uluslararası Kriz Yönetimi dersi 4. sınıfta ise seçmeli olarak Türkiye AB ilişkileri dersi bulunmaktadır.

214 Bölüm 2018-2019 yılı itibariyle öğrenci alımına başlamıştır. Üniversitenin web sayfasında sadece birinci sınıfa ait ders içerikleri bulunmaktadır.

215 Üniversitede üç dönem (güz-bahar-yaz dönemi) eğitim verilmektedir. 1. sınıfta Siyaset Teorisi, Türkiye'de Siyaset ve Toplum, Introduction to Comperative Political Systems dersleri zorunludur. Fakülte ve üniversite geneline ait seçmeli dersler bulunmaktadır.

${ }^{216}$ 3. sınıfta Siyasi Tarih dersi seçmelidir. 4. sınıfta Uluslararası ilişkiler, AB ve Türkiye dersleri seçmelidir.

217 1. sınıfta Siyaset Bilimine Giriş I ve II, Siyasi Tarih I ve II dersleri zorunludur. 2. sınıfta Uluslararası Politika Idare Hukuku dersleri zorunludur.

218 1. sınıfta Siyaset Bilimine Giriş, Karşılaştırmalı Siyasal Rejimler dersleri zorunludur. 2. sınıfta Siyasi Düşünceler Tarihi I ve II, Siyaset Sosyolojisi I ve II dersleri zorunludur.

219 3. sınıfta Uluslararası Hukuk, Uluslararası Ilişskiler ve Politikalar dersleri seçmelidir. 4.sınıfta Uluslararası Örgütler dersi seçmelidir. 4. sınıfta Türk Siyasi Hayatı I ve II dersleri zorunludur.

220 Siyaset Bilimine Giriş, Uluslararası ilişsilere Giriş, Almanya Türkiye Karşılaştırmalı Siyasal Sistemler, Alman Siyasi Tarihi, Türk Siyasi Hayatı dersleri bulunmaktadır.

221 1. Sınıfta Siyaset Bilimine Giriş I ve II derslerinin yanı sıra Yönetim Bilimi dersi de bulunmaktadır. 2. sınıfta Idare Hukuku dersi zorunludur. 3. sınıfta Türk Siyasi Yapısı, Türkiye AB ilişkileri dersleri zorunludur.

222 3. sınıfta seçmeli olarak Ortadoğu Tarihi, Siyasi Tarih Uygulamaları I ve II dersleri bulunmaktadır. 4.

sınıfta seçmeli olarak Uluslararası ilişkiler, Türk Dış Politikası, Ileri Siyasi Tarih Uygulamaları I ve II dersleri bulunmaktadır.

${ }^{223}$ Eğitim dili Ingilizcedir. 3. Sınıfta Comparative Political Systems, European Integration Process dersleri zorunludur. bulunmaktadır.

224 1. sınıfta Siyaset Bilimine Giriş I ve II, 2. Sınıfta Siyasal Düşünceler Tarihi I ve II, 3. Sınıfta Türk Siyasal Hayatı I ve II, 4. sınıfta Siyaset Kuramı I ve II dersleri zorunlu olarak verilmektedir. Seçmeli olarak ise 3. sınıfta Idare Hukuku, Avrupa Birliği Kurumları ve Politikaları dersleri bulunmaktadır.

225 1. sınıfta Siyasi Tarih dersi 4. sınıfta ise Devletler Hukuku dersi zorunludur.

${ }^{226}$ 2. sınıfta Turkish Politics, History of Political Thought, 3. Sınıfta International Environmental Policy

227 Bölüm, Insan ve Toplum Bilimleri Fakültesinde bulunmaktadır. 4. Sınıfta Global Politics, Turkey- EU Relations, Global Governance dersleri zorunlu olarak bulunmaktadır. Seçmeli olarak ise 4. Sınıfta Administrative Law dersi bulunmaktadır.

228 4. sınıfta Avrupa Yönetsel Alanı ve Türkiye isimli zorunlu bir ders bulunmaktadır. 
Merve Mescioğlu Fedai - Recep Fedai

${ }^{229}$ Bölümün eğitim dili ingilizcedir. Türk Siyasal Hayatı, Karşılaştırmalı Siyasal Sistemler dersleri zorunludur.

${ }^{230}$ 2. sınıfta Türkiye'nin Toplumsal Yapısı ve Türk Siyasi Hayatı, Siyasal Düşünceler Tarihi I ve II dersleri zorunlu olarak verilirken Çağdaş Devlet Sistemleri, Küresel Çevre Sorunları dersleri seçmelidir.

${ }^{231}$ 2. ve 3. sınıfta Siyasi Tarih I ve II dersleri zorunlu olarak verilmektedir. 3. sinifta Uluslararası Hukuk dersi zorunlu iken Türk Dış Politikası dersi seçmelidir. 4. sınıfta Türkiye AB İlişkileri dersi zorunludur.

232 2. sınıfta zorunlu olarak Siyasi Tarih dersi seçmeli olarak ise Türk Dış Politikası dersi bulunmaktadır. 3. Sınıfta Uluslararası Hukuk dersi zorunlu Uluslararası Örgütler dersi ise seçmelidir. 